\title{
How Tyranny Paved the Way to Wealth and Democracy: The Democratic Transition in Ancient Greece
}

\author{
Robert K. Fleck \\ Department of Agricultural Economics and Economics \\ Montana State University \\ Bozeman, MT 59717 \\ phone: (406) 994-5603 \\ e-mail:rfleck@montana.edu \\ F. Andrew Hanssen \\ John E. Walker Department of Economics \\ Clemson University \\ Clemson, SC 29634 \\ phone: (864) 656-5474 \\ e-mail: fhansse@clemson.edu
}

October 1, 2010

\begin{abstract}
When a ruling elite is unable to commit to future growth-promoting policies, it may cede political power to a broader segment of the public, as in North and Weingast (1989). Alternatively, as we show in this paper, commitment may be achieved by moving in the opposite direction: installing a single authoritarian ruler who favors growth-promoting policies. Although this narrows the distribution of power in the short run, it may - as our model illustrates - be a step toward, not away from, democracy. We apply the model to ancient Greece. Many of the famously democratic poleis (city-states) of Greece's Classical period were ruled by tyrants in the earlier Archaic period. The tyrannies of Archaic Greece were transitory institutions, generally lasting only a few decades, with strong similarities across poleis in the factors that led to their appearance and the types of policies enacted. Using a unique data set, we examine the relationships between the potential for economic growth, Archaic period tyranny, and Classical period democracy. We conclude that a high potential for economic growth led to a pro-growth political institution (the tyrant) that led in turn to increased wealth and, eventually, to democracy. These findings are consistent with critical junctures theory - the institutional path determines both wealth and democracy.
\end{abstract}

We are deeply indebted to Josh Ober for making available to us a wealth of ancient Greek data, and for inviting us to participate in Stanford University's Emergence of Cooperation Colloquium. We also benefitted from numerous discussions with other Colloquium participants. For helpful comments on this paper, we thank Yoram Barzel, Ron Johnson, Ian Morris, Josh Ober, and seminar participants at Colby College, the University of Washington, and the 2009 Michael P. Malone Memorial Conference. 
When Greece had grown more powerful and was still more than before engaged in the acquisition of wealth, tyrannies were established in the cities.

-Thucydides (1 13.1) [quoted in Ure $(1922,9)]$

[Greek] Tyranny was an important stage in the process toward democracy.

-Raaflaub and Wallace $(2007,43)$

\section{INTRODUCTION}

The cause of the well-documented (and robustly positive) cross-country and time series association between income and democracy has been hotly debated. Two principal schools of thought have emerged. The older has roots in Lipset's (1959) seminal work, is variously referred to as "Lipset's law," the "democratic transition," and the "modernization hypothesis," and emphasizes the causal role of income in the rise of democracy. The other is sometimes labeled the "critical junctures" hypothesis, because it maintains that institutional divergences at critical points explain differences in both wealth and democracy (see, e.g., Acemoglu, Johnson, Robinson, and Yared 2009). According to the modernization hypothesis, wealth causes democracy, so espousers of democracy should focus on fostering economic growth. According to the critical junctures hypothesis, the institutional base is the crucial factor - if there is a prescription, it would be "get the institutions right."

For the most part, the debate has focused on recent history, with scholars exploiting similar (often the same) data sets. In this paper, we propose to add to the debate by investigating a much earlier era, that of ancient Greece. Nearly everyone is aware that Greece is the birthplace of democracy. Perhaps less well-known is the fact that there were hundreds of poleis (city-states) in ancient Greece, that poleis became democratic gradually, and that poleis varied in levels of democracy achieved (see, e.g., Fleck and Hanssen 2006). Ancient Greece is thus a potentially 
valuable source of information on democratic transitions. ${ }^{1}$ Yet until recently, data of the kind necessary to study these transitions were simply not available.

Systematic empirical analysis of the democratic transition in ancient Greece can now be undertaken, thanks to the publication of the Inventory of Archaic and Classical Poleis (Hansen and Nielsen 2004). The volume summarizes all that is known about the many poleis of ancient Greece, and categorizes poleis by the nature of their political institutions. Although the Inventory's information is crude by the standards of data on modern countries, it allows us to explore the rise of democracy in manner heretofore impossible.

"Rise of democracy" is the operative phrase: All of the poleis of ancient Greece entered the Archaic period (800-490 B.C.E.) as aristocracies, with power concentrated in the hands of a few noble families, and exited the Classical era (490-323 B.C.E.) with more broadly representative systems. $^{2}$ The intervening Archaic period was characterized by rapid economic growth and the appearance of a figure who came to encapsulate the era: the tyrant. Indeed, the tyrant was such a well-known phenomenon that scholars have referred to the Archaic period as "the age of the tyrant" (e.g., Andrewes 1956, 8; Raaflaub and Wallace 2007, 43).

The Archaic period tyrant was not the despot the term would later signify. As Andrewes $(1956,7)$ writes, "A tyrant, in these Greek terms, is not necessarily a wicked ruler, but he is an

${ }^{1}$ Indeed, given that more than 1000 Greek poleis have been identified, one could argue that most of the transitions to democracy in history occurred in ancient Greece.

${ }^{2}$ These ranged from oligarchies, which used property requirements to restrict access to the most important public positions, to democracies, where the public assembly - open to the broad mass of the citizenry - controlled policymaking. In fact, both oligarchy and democracy were much more representative systems than lineage-based aristocracy that had preceded them. See Grant (1987) for a review of political developments over the Archaic Period in several dozen poleis. We should note (as many have) that in ancient Greece, the "broad mass of the citizenry" was strictly male (women possessed no formal political rights) and excluded potentially large populations of slaves (e.g., Athens) or serfs (e.g., Sparta). Women in a (very) few poleis had significant rights to hold property - see Fleck and Hanssen (2009). 
autocrat (and generally a usurper) who provides a strong executive." ${ }^{33}$ In the same fashion, Aristotle distinguished between the "all bad" tyrants of his own day (the late Classical period) and the "half bad" Archaic period tyrants, who contributed to the public good. ${ }^{4}$

These tyrants appeared at an unusually propitious time in Greek history. By the start of the Archaic period, Greece had recovered sufficiently from the collapse of the earlier Mycenaean civilization that its people were in a position to participate in (and expand upon) the well-developed trading networks of the Near East - the very networks that had made Mycenae rich. Indeed, it might be more accurate to say that the Archaic period began when Greece reached a level of development sufficient to prompt re-integration into regional trading networks. The tyrant's emergence was linked intimately to intra-elite conflict sparked by the commercial potential that reintegration represented. Commercial expansion and intra-elite conflict both figure heavily in historical accounts of Archaic period tyranny.

The Archaic period tyrants shared a number of characteristics. First, they came from noble families, and typically from commercially oriented segments of the nobility. Second, they were found primarily in commercially oriented poleis, such as Athens, Corinth, and Argos, rather than in

\footnotetext{
${ }^{3}$ Writers from the first half of the Classical period, such as Sophocles and Herodotus, appear to use the words tyrannos (tyrant) and basileus (king) interchangeably (Parker 2007, 15). And while Archaic age poets such as Theognis write disparagingly of tyrants, it is the tyrant's concern with commerce and the increased equality across classes that results from the tyrant's actions that these poets find displeasing. Ferrill $(1978,385)$ writes, "After 400 B. C. tyranny can be regarded in the traditional manner as the government of an arbitrary, despotic, and frequently cruel ruler who is completely dominant in the state. In this second period tyranny is unpopular and the very opposite of democratic institutions. All the modern connotations of the word tyrant are appropriate for this second period of Greek tyranny."

${ }^{4}$ In sharp contrast to the modern notion of tyrants as despots, Archaic period tyrants were said to "maintain justice" (Hammond 1982, 350). The tyrant Orthagoras of Sicyon had a reputation for "mild and almost constitutional government" (Grant 1987, 101). The tyrants Periander of Corinth and Pittacus of Mytilene were included by ancient writers among the Seven Sages (men of profound wisdom and devotion to truth and justice).
} 
agriculturally oriented poleis, such as Thebes, Sparta, and Arcadia. Third, they invested in infrastructure (aqueducts, pump houses, port facilities) and standardized weights and measures. ${ }^{5}$ Fourth, the reign of a tyrant typically ended with his death or exile, or perhaps that of his son - and once tyranny disappeared, it was gone from that polis for good. ${ }^{6}$ Fifth, many of the poleis where tyrants ruled became the broadest, most inclusive democracies of the Classical period.

In order to provide a clear theoretical framework for our analysis, we begin by developing a formal model. The model allows us to examine the way exogenous economic conditions - more specifically, opportunities for investment to generate economic growth - influence the adoption and success of different types of government institutions. Building on a now-large literature, we focus on the incentives of a ruling elite to extend policymaking power to others. ${ }^{7}$ Our model marries different approaches - divergence in the preferences of the elite, time-inconsistency problems - in a way that generates novel predictions. Most notably, it predicts that when a divided elite is unable to commit credibly to future growth-promoting policies, the move to tyranny may be a step toward, not away from, democracy.

The model motivates our empirical analysis. To understand our econometric approach, it is essential to recognize that not all poleis had tyrants, not all tyrannies became democracies, and not all democracies were once tyrannies. Moreover, the historical record does not provide a complete and accurate set of dates for different events. As a result, systematic relationships are not immediately obvious in the data. Yet by using our theoretical framework to guide our analysis, and

${ }^{5}$ Jeffrey $(1976,136)$ writes, "Economic reforms like this were one mark of the good tyrant."

${ }^{6}$ Raaflaub and Wallace $(2007,42)$ write, "tyrannies typically lasted no more than two generations."

${ }^{7}$ See North and Weingast (1989), Kiser and Barzel (1991), Justman and Gradstein (1999), Acemoglu and Robinson (2000, 2001), Barzel (2000), Fleck (2000), Conley and Temimi (2001), Lizzeri and Persico (2004), Llavador and Oxoby (2005), Fleck and Hanssen (2006, 2009), Jack and Lagunoff (2006). 
by exploiting some key facts about the broader historical context, we are able to segment our data set in ways that allow us to identify systematic relationships between early tyranny, later democracy, and proxies for economic conditions. ${ }^{8}$ We complement our econometric analysis with historical case studies of the best known tyrants (and near-tyrants), which serve both to confirm our interpretations and to provide more detail on the circumstances under which tyrants arose, and on what tyrants did.

We have three main empirical findings. First, the great preponderance of tyrants appeared among poleis located on the coast. These were the poleis for which the potential gains from Archaic period commercial expansion would have been largest and, hence, most likely to produce divisions among the elite (for example, along old agriculture versus new commerce lines). ${ }^{9}$ Second, poleis that had tyrants were much more likely to become democracies, rather than oligarchies, in the later Classical period, consistent with tyranny serving as a bridge to democracy. Indeed, the importance of tyranny's link to democracy is underscored by the fact that potential for economic growth (measured as a location on the coast) predicts democracy only through its effect on tyranny. Third, using a proxy for wealth (major public buildings) we find that democratic ex-tyrannies were the wealthiest poleis in ancient Greece. As a result, there is a strong Classical period relationship between democracy and wealth, just as one observes in the world today.

From our findings we conclude that the relationship between growth and democracy is

\footnotetext{
${ }^{8} \mathrm{We}$ restrict our sample to poleis of mainland Greece, which allows us to capture the time-series dimension of the institutions. On the mainland, tyrannies were established only during the Archaic period, and democracies only during the Classical period ("the age of democracy").

${ }^{9}$ The historical record indicates enormous Archaic period growth (e.g., Morris 2009); however, no precise measures of economic growth by poleis are available. Thus, to proxy for exogenous potential for growth, we classify poleis by whether or not they were located on the coast; i.e., in position to take advantage of the well-established and rapidly growing regional trade networks that made Greece wealthy. This works only for the Archaic period - the more encompassing trade networks that emerged during the Classical period involved many inland poleis, as well.
} 
strong, but more complex than the modernization hypothesis would lead one to predict. A high potential for economic growth (coastal location) leads to a pro-growth political institution (the tyrant) that leads in turn to increased wealth and to democracy. In this respect, our results are consistent with critical junctures theory (Acemoglu, Johnson, Robinson, and Yared 2009) - the institutional path (in this case, whether or not a tyrant rules) determines both wealth and democracy. ${ }^{10}$

Our analysis also builds on the divided elite models of Lizzeri and Persico (2002) and Llavador and Oxoby (2005), who propose that the franchise is extended by commercially oriented elements of the elite in order to create political support for policies with diffuse benefits, such as public goods investment. ${ }^{11}$ Although many of the circumstances we describe in this paper are similar (namely, a divided elite with a pro-growth element seeking growth-enhancing public goods), our model can explain why, rather than expanding the franchise, Greek poleis narrowed it concentrating power in the hands of a tyrant - and yet this nevertheless led to democracy in the longer run. ${ }^{12}$

This paper is an extension and deepening of our earlier work on Greek democracy (Fleck and

${ }^{10}$ Our conclusions support Aristotle's contention that Greek tyranny was "a necessary step in the evolution toward democracy," a statement suggesting Aristotle believed in the importance of the institutional path. The quotation is from Ferrill $(1978,385)$. See Appendix A for a summary of explanations offered by classicists for the appearance of the tyrant.

${ }^{11}$ The franchise extension is promoted by commercial interests and resisted by landed interests; the commercial interests enfranchise less wealthy traders and urban dwellers, thereby creating support for the policies they desire (e.g., investment in infrastructure).

${ }^{12}$ See also Barro (1997, 1999), Acemoglu, Johnson, Robinson, and Yared (2008), and Acemoglu, Johnson, Robinson and Yared (2009). For additional work related to our analysis of democracy and economic performance, see Lipset (1959), Alesina and Drazen (1991), Fernandez and Rodrik (1991), Olson (1993), Alesina and Rodrik (1994), Londregan and Poole (1996), McGuire and Olson (1996), Justman and Gradstein (1999), Lott and Kenny (1999), Rodrik (1999), Conley and Temimi (2001), Minier (2001), and Mueller and Stratmann (2003). 
Hanssen 2006). In our 2006 paper, we sought to explain differences in levels of democracy across Greek poleis in the Classical period. Our explanation turned on exogenous variations in the nature of the landscape, which produced corresponding differences in the returns to establishing property rights, and hence (we posit) to expanding political rights. The analysis in this paper also makes use of exogenous variation in landscape, but employs a data set that enables us to explore the institutional path followed in the transition to democracy in ancient Greece. ${ }^{13}$

\section{STARTING POINTS FOR THE ANALYSIS}

In this section, we review two features of the Archaic period that are essential starting points for our analysis. First, the Archaic period was a uniquely propitious time for economic growth. Second, this potential for economic growth was (at least initially) greater for coastal poleis than for inland poleis (which possessed more fertile land and worse access to the sea), creating more acute intra-elite divisions along the coast.

\section{A unique opportunity for commercial expansion}

The Archaic period was a particularly opportune time for Greek expansion. Because centuries of contraction had followed the collapse of Mycenaean civilization (see Appendix A), substantial idle land and resources were available to the rapidly growing Greek population. Furthermore, because Greece was located close to the economically advanced and commercially aggressive Near East, Archaic poleis were quickly able to establish (re-establish, in fact) important

\footnotetext{
${ }^{13}$ It also allows us to confirm the transition for a larger set of poleis, and to employ econometric analysis (our 2006 paper relied on case studies). In this paper, the exogenous variation is location on a coast, while in Fleck and Hanssen (2006) the variation was in the size of fertile plains (which proxied for the return to difficult-to-monitor investment). The two variables are related-coastal poleis have smaller fertile plains, because the largest fertile valleys are inland.
} 
trading networks. ${ }^{14}$ The economic dynamism of Archaic period Greece can be seen in its technological innovation; Boardman $(1982,449)$ writes that the seventh century is when we first see "Greek studios in command of new techniques and producing wares which we would regard as wholly Hellenic in character."15 The dynamism is also reflected in a wave of Greek colonization Graham (1982, 160-2) lists 139 colonies founded by Greek poleis between 800 and 500 B.C.E. Starr $(1982,417)$ writes of the Archaic Period:

During the three centuries ... 800-500 B.C. the economic and social infrastructure of the Greek world underwent massive alterations which set the framework for the Classical age. ... Economically the volume of output increased tremendously, as measured against earlier centuries, and was much more diversified in types of products and styles. . . [O]verseas trade leaped forward in the centuries under discussion. A wide interest in economic gain can be detected in the more active states, at least among their urban elements.

Standard quantitative measures of economic growth (e.g., GDP) are not available for the period, but broader measures, such as energy capture (Morris 2009, 12), show striking increases.

\section{More acute intra-elite divisions along the coast}

Accessing sea-based trade routes was obviously less difficult for coastal poleis than for inland poleis. ${ }^{16}$ Add to this the fact that coastal poleis had land that was less fertile overall, and it

\footnotetext{
${ }^{14}$ Most of Greece's trading partners from the Mycenaean period did not suffer Mycenae's profound destruction, so Archaic Greece was able to take advantage of the same trading networks that had enriched Mycenaean Greece. Starr $(1982,419)$ writes that Greece's economic success in the Archaic period was promoted by "the progress of the Mediterranean world in the early centuries of the first millennium B.C., and in particular the developments in the Near East... Though much shaken by the invasions at the end of the Bronze Age and disruptions which had reduced Greece to a very simple level, the Near East rallied much more rapidly, and by 800 was establishing extensive cultural and economic interconnections."

${ }^{15}$ Boardman and Hammond (1982, xiv) write that "intercourse with the older civilizations of the east and Egypt opened Greek eyes to materials, techniques and trading profits denied to them since the collapse of their Bronze Age [Mycenaean] civilization." In addition, the early Archaic period saw Greece begin to cultivate improved varieties of olives and grapes, imported from Asia Minor (Boardman 1977).

${ }^{16}$ It is notable that more than 95 percent of the 139 Greek colonies known to have been founded between 800 B.C.E. and 500 B.C.E. (Graham 1982, 160-2) were founded by poleis located on the coast.
} 
becomes clear that the potential benefits to commercial expansion were greatest for poleis located on the coast. ${ }^{17}$ It was this potential for commercial expansion that divided the elites on the coast (by creating a more heterogenous set of interests), but left inland elites (with more homogenous interests) relatively united.

In coastal poleis, while some members of the (traditionally land-based) aristocracy resisted commercial development, others were its most aggressive promoters - indeed, Starr $(1982,421)$ refers to them as the "galvanizing factor":

The eager, ruthless drive for wealth . . . of the Greek upper class in the Archaic era is abundantly noted ... Solon says that those who are most wealthy "have twice the eagerness that others have."

Hammond $(1982,335)$ writes that portions of the Bacchiadae, coastal Corinth's aristocracy, "took steps to stimulate overseas trade ... provide suitable conditions for workshops to be set up, and then enjoy the expanding market," and that Athens' development was spearheaded by certain of the Eupatrids, the Athenian nobility. At the same time, a new class of wealthy non-noble citizens was emerging, often referred to by the pejorative kakoi, meaning "base" or "ugly," although "nouveaux riche" might be a more accurate transliteration. ${ }^{18}$ The early sixth century Athenian leader Solon

${ }^{17}$ As Jeffrey $(1976,23)$ writes, "The inhabitants [of Greece] tended to cluster in many highland or lowland plains, in river valleys, along coastal strips backed by mountains." The "coastal strips backed by mountains," location of such poleis as Athens, Argos, and Corinth, contained less fertile land, not surprisingly. By contrast, inland poleis Sparta and Thebes were famous for their fertile valleys. Forrest $(1968,13)$ writes of the region where Sparta was located, "Thus there are two main areas of cultivation; one . . . was Messenia, the rich, utterly flat, alluvial plain of the Paimos and its tributaries; the other ... Laconia's central plain, some twenty miles long, some seven miles wide, well-watered and fertile," and Semple $(1921,55)$ writes that the Messenian grain fields "enjoyed a rare reputation for productivity from very early times." Thebes was located in the center of an agriculturally rich part of Greece called Boeotia. Boeotian agricultural production was so successful, and the peoples of Boeotia so widely known for being well-fed, that the insult "Boeotian pig" became common (Demand 1982, 10).

${ }^{18}$ Some have suggested that kakoi were urban bourgeoisie of strictly commercial orientation; others that they were middling landholders of non-aristocratic descent (see the discussion in Starr 1977, Ch. 6). 
considered kakoi to be men of power - and, indeed, altered franchise rules to include them in the policymaking process - while Archaic period poets, drawn principally from the nobility, deplored their rise (e.g., Cartledge 1998, 79).

In the fertile inland valleys, by contrast, the elite did not divide. For example, Forest (1982, 289) writes about the inland plains of Boeotia:

The reason [for the lack of intra-elite division] is not far to seek. The Boeotian plain was large enough and fertile enough to keep the Boeotians happy ... no great urge to colonize nor to exploit the new economic opportunities with or after colonization elsewhere... Boeotia, then, was essentially an agricultural area, and a stale agrarian economy does not breed social, political, or even much cultural excitement.

Indeed, the leading Boeotian polis, Thebes (which would become powerful enough to rival Athens and Sparta late in the Classical period) passed a law during the Archaic period that permitted only those who had abandoned commercial pursuits for at least ten years to hold public office. ${ }^{19}$ The inland poleis Sparta went even further, banning commercial activity by its ruling elite completely. ${ }^{20}$

Boardman and Hammond (1982, xv) sum up the differences between coast and interior:

The social and political effects of the economic revolution became apparent first in those states of old Greece which lay closest to the Isthmus [i.e., along the coast emphasis ours] and were subject to the impact of new forms of wealth. The longestablished rule of landed aristocracies of birth collapsed through divisions within the upper echelons of society, and the Greek genius for political experimentation and for political strife was given free rein.... But in other parts of the mainland [i.e., inland - emphasis ours] the traditional way of life persisted and modifications came slowly.

\section{THE MODEL}

This section develops a model to illuminate the incentives facing ruling elites when entering

${ }^{19}$ Aristotle (Pol. 1278a25, cited in Forest 1982, 282).

${ }^{20}$ Sparta put extraordinary emphasis on maintaining the ruling elite's homogeneity, even referring to members of the elite (who were the only "citizens" of Sparta) as homoioi, meaning "the equal ones" or "the similars." See, e.g., Freeman $(1999,97)$ and Hanson $(1999,385)$. 
a period with opportunities for economic growth. To keep the model simple, we consider three stylized types of government (oligarchy, democracy, tyranny), three time periods (just enough to allow the possibility of choosing a transitory institution), and a population that is composed of elites (whom we refer to as "oligarches") and the demos. Our main results hinge on a division within the elite and the consequent difficulty in committing to future policy. To allow between-group differences in policy preferences, we assume the government must set the quantities of two public goods. One of these public goods increases the returns to stylized "entrepreneurs" who have made successful investments in commercial activities - these entrepreneurs are a subset of the oligarches and a subset of the demos. The other public good has value only to the demos. (Instead of a public good, this could be money divided equally among the demos.) By defining groups and public goods in this manner, we can characterize policy-driven divisions between the oligarches and the demos, as well as within each of those groups.

\section{Assumptions}

\section{Government Types}

Type O Oligarchy. The oligarches vote, choosing the Condorcet winner for public good spending and for the future type of government. ${ }^{21}$

Type D Democracy. The members of the demos vote (along with the oligarches), choosing the Condorcet winner for public good spending and for the future type of government.

Type T Tyranny. A single oligarch of a known type (e.g., entrepreneur) is chosen to rule, then proceeds to set the policies favored by his or her type. Tyranny has undesirable features that create costs of $\tau$ per person. A tyrant will rule for at least one period and will remain in power unless a majority of the oligarches decide to remove him. Removing the tyrant requires a cost $\rho$, which will be either (i) shared equally per

${ }^{21} \mathrm{~A}$ Condorcet winner is an outcome that beats all the alternative outcomes in pairwise voting. By looking at the Condorcet winner (as opposed to, e.g., a plurality rule winner), we rule out standard problems of voting mechanisms (e.g., cycling among outcomes). 
capita among the oligarches, thus reestablishing oligarchy, or (ii) if the oligarches so choose, shared equally per capita among the oligarches and the demos, thus establishing democracy.

\section{$\underline{\text { Order of Events }}$}

Period 1 Oligarches select government type for Period 2: O, D, or T

Period 2 Individuals make Period 2 investment decisions: $\mathrm{k}_{\mathrm{i} 2}$ Individuals observe Period 2 success (or not): $\mathrm{s}_{\mathrm{i} 2}$

Government sets Period 2 levels of public goods: $g_{2}$ and $d_{2}$ Individuals receive Period 2 benefits: $b_{\mathrm{i} 2}$ Relevant groups select government type for Period 3: O, D, or T

Period 3 Individuals make Period 3 investment decisions: $\mathrm{k}_{\mathrm{i} 3}$ Individuals observe Period 3 success (or not): $\mathrm{s}_{\mathrm{i} 3}$

Government sets Period 3 levels of public goods: $g_{3}$ and $d_{3}$ Individuals receive Period 3 benefits: $b_{i 3}$

\section{$\underline{\text { Population Characteristics and Outcomes for Individuals }}$}

The population consists of six groups. Denote the size of the groups as follows: $\underline{\mathrm{O}}_{\mathrm{E}}$, the oligarch "entrepreneurs," for whom g generates sure benefits; $\underline{\mathrm{O}}_{\mathrm{L}}$, the oligarch "landlords," for whom g generates no benefits; $\underline{\mathrm{O}}_{\mathrm{LE}}$, oligarches for whom $\mathrm{g}$ may or may not generate benefits; $\underline{\mathrm{D}}_{\mathrm{E}}, \underline{\mathrm{D}}_{\mathrm{L}}$, and $\underline{\mathrm{D}}_{\mathrm{LE}}$ for similarly defined components of the demos. To simplify the notation, denote the total size of the oligarch population as $\underline{\mathrm{O}}$ and the total size of the demos population as $\underline{\mathrm{D}}$. Neither $\underline{\mathrm{O}}$ nor $\underline{\mathrm{D}}$ changes over time.

For individual i, the probability of success $\left(\mathrm{p}_{\mathrm{it}}\right)$ depends on that individual's investment for each period $t\left(\mathrm{k}_{\mathrm{it}}\right)$ and an exogenous parameter $\left(\sigma_{\mathrm{i}}\right)$, defined so that the successful remain successful (i.e., period 2 success guarantees period 3 success):

$$
\begin{aligned}
& \mathrm{p}_{\mathrm{i} 2}=\operatorname{prob}\left(\mathrm{s}_{\mathrm{i} 2}=1\right)=\sigma_{\mathrm{i}} \mathrm{k}_{\mathrm{i} 2} \\
& \mathrm{p}_{\mathrm{i} 3}=\operatorname{prob}\left(\mathrm{s}_{\mathrm{i} 3}=1\right)=\mathrm{s}_{\mathrm{i} 2}+\left(1-\mathrm{s}_{\mathrm{i} 2}\right) \sigma_{\mathrm{i}} \mathrm{k}_{\mathrm{i} 3}
\end{aligned}
$$

where $\mathrm{s}_{\mathrm{it}}=1$ indicates success (with $\mathrm{s}_{\mathrm{it}}=0$ otherwise) and

$$
\sigma_{\mathrm{i}}=0 \quad \text { if individual } \mathrm{i} \text { is of type } \mathrm{O}_{\mathrm{L}} \text { or } \mathrm{D}_{\mathrm{L}}
$$




$$
\begin{array}{ll}
\sigma_{i}=1 & \text { for members of } \mathrm{O}_{\mathrm{E}} \text { or } \mathrm{D}_{\mathrm{E}} \\
\sigma_{\mathrm{i}}=\sigma_{\mathrm{O}} & \text { for members of } \mathrm{O}_{\mathrm{LE}} ; 0<\sigma_{\mathrm{O}}<1 \\
\sigma_{\mathrm{i}}=\sigma_{\mathrm{D}} & \text { for members of } \mathrm{D}_{\mathrm{LE}} ; 0<\sigma_{\mathrm{D}}<1
\end{array}
$$

For each individual, political preferences over public goods $\left(g_{t}\right.$ and $\left.d_{t}\right)$ and type of government, along with the choice of $\mathrm{k}_{\mathrm{i}}$, are based on maximizing the individual's expected returns, with the following constraints: $0 \leq \mathrm{g}_{\mathrm{t}} \leq 1 ; 0 \leq \mathrm{d}_{\mathrm{t}} \leq 1 ; 0 \leq \mathrm{g}_{\mathrm{t}}+\mathrm{d}_{\mathrm{t}} \leq 1 ; 0 \leq \mathrm{k}_{\mathrm{it}} \leq 1$. The returns are defined as:

$$
\begin{aligned}
& \mathrm{b}_{\text {Oit }}=\beta_{\mathrm{O}} \mathrm{g}_{\mathrm{t}} \mathrm{k}_{\mathrm{it}} \mathrm{s}_{\mathrm{it}}-\mathrm{k}_{\mathrm{it}}-\gamma \mathrm{g}_{\mathrm{t}}-\mathrm{r}_{\mathrm{it}} \rho-\tau \mathrm{T}_{\mathrm{t}} \\
& \mathrm{b}_{\text {Dit }}=\beta_{\mathrm{D}} \mathrm{g}_{\mathrm{t}} \mathrm{k}_{\mathrm{it}} \mathrm{s}_{\mathrm{it}}-\mathrm{k}_{\mathrm{it}}-\gamma \mathrm{g}_{\mathrm{t}}-\mathrm{r}_{\mathrm{it}} \rho-\tau \mathrm{T}_{\mathrm{t}}-\mu\left(\delta-\mathrm{d}_{\mathrm{t}}\right)^{2}
\end{aligned}
$$

with the following exogenous parameters: $\beta_{\mathrm{O}} \geq 0, \beta_{\mathrm{D}} \geq 0, \gamma \geq 0, \rho \geq 0, \tau \geq 0, \mu \geq 0, \delta \geq 0 .{ }^{22}$ Here, $\mathrm{T}_{\mathrm{t}}=1$ indicates a tyrant ruling in period $\mathrm{t}$ (with $\mathrm{T}_{\mathrm{t}}=0$ otherwise), and $\mathrm{r}_{\mathrm{it}}$ indicates individual i's share of the costs incurred if a tyrant is removed.

\section{Implications}

The model shows not only that an exogenous increase in the expected returns to investment $\left(\beta_{\mathrm{O}}, \sigma_{\mathrm{O}}, \beta_{\mathrm{D}}, \sigma_{\mathrm{D}}\right)$ can lead to institutional change, but that the direction of the change depends on specific circumstances. One might observe an immediate and lasting broadening of political rights (i.e., a transition from $\mathrm{O}$ to $\mathrm{D}$ ), an immediate and lasting narrowing of political rights (i.e., a transition from $\mathrm{O}$ to $\mathrm{T}$ ), or a transitory narrowing of political rights followed by a broadening of political rights (i.e., a transition from $\mathrm{O}$ to $\mathrm{T}$ and then back to $\mathrm{O}$, or a transition from $\mathrm{O}$ to $\mathrm{T}$ and then to D).

Under several sets of circumstances, oligarchy $(\mathrm{O})$ will be stable. Perhaps most obviously,

${ }^{22}$ The parameters should be interpreted as follows: $\beta_{\mathrm{O}}$ and $\beta_{\mathrm{D}}$ scale returns to successful entrepreneurship, $\mu$ and $\delta$ scale the value of the public good $\mathrm{d}_{\mathrm{t}}$ to the demos, with a functional form consistent basic consumer surplus arising from, e.g., a generic linear demand curve and constant marginal cost; $\gamma$ is the per capita cost of $g ; \rho$ indicates (as noted earlier) the cost of removing a tyrant; $\tau$ indicates (as noted earlier) the cost of having a tyrant rule. Note that the constant returns to $\mathrm{k}$ will lead to corner solutions $(\mathrm{k}=0$ or $\mathrm{k}=1)$, which simplifies our exposition. 
when the elite is dominated by landlords $\left(\underline{\mathrm{O}}_{\mathrm{L}}>.5 \underline{\mathrm{O}}\right)$, there will be neither a political transition nor an economic transition. Similarly, when the expected returns to potential entrepreneurs among the elite are low (e.g., sufficiently small $\sigma_{\mathrm{O}}$ and $\beta_{\mathrm{O}}$ ), there will be neither a political transition nor an economic transition, even if there are many potential entrepreneurs (e.g., $\left.\underline{\mathrm{O}}_{\mathrm{IE}}=\underline{\mathrm{O}}\right)$. Oligarchy can also be stable when, in contrast to the scenarios just described, an economic transition occurs. This is the result when entrepreneurship among the oligarches has sufficiently high growth potential (e.g., high $\sigma_{\mathrm{O}}$ and $\beta_{\mathrm{O}}$, with $\underline{\mathrm{O}}_{\mathrm{L}}<.5 \underline{\mathrm{O}}$ ). The reasoning is straightforward. With high success rates and high returns for type $\mathrm{O}$ entrepreneurs, the oligarches can commit credibly under oligarchy $(\mathrm{O})$ to growth-promoting policy $\left(\mathrm{g}_{2}=\mathrm{g}_{3}=1\right)$, and there is no incentive for them to change government type. ${ }^{23}$

Yet in other circumstances, there will be a democratic transition. One scenario is for the oligarches in period 1 choose democracy for period 2. This rapid and permanent transition to democracy will occur if the oligarch majority would like to commit to $\mathrm{g}_{2}=\mathrm{g}_{3}=1$, but cannot credibly do so under oligarchy (because of a time-inconsistency problem arising from too few successful oligarches in period 2), yet democracy will establish a credible commitment. Conditions leading to this arise when (i) economic growth potential among the oligarches is sufficient to make $g_{2}=g_{3}=1$ desirable ex ante to the majority of oligarches, but not high enough to generate time-consistent majority rule decisions under oligarchy, (ii) there is sufficiently high growth potential among the demos (e.g., high $\sigma_{\mathrm{D}}$ and $\beta_{\mathrm{D}}$ ) to create a period 2 democratic majority in favor of a sufficiently high

${ }^{23}$ To show why this holds, choose any value of $\sigma_{\mathrm{O}}$ such that $\sigma_{\mathrm{O}}>\left[\left(\underline{\mathrm{O}}-2 \underline{\mathrm{O}}_{\mathrm{E}}\right) / 2 \underline{\mathrm{O}}_{\mathrm{LE}}\right]$, and then choose a sufficiently large value of $\beta_{\mathrm{O}}$ so that $\beta_{\mathrm{O}}>(\gamma+1) / \sigma_{\mathrm{O}}$. In this case, the returns to investment are sufficiently great that type $\mathrm{O}_{\mathrm{LE}}$ individuals will invest (i.e., set $\mathrm{k}=1$ ) if they expect $\mathrm{g}=1$ in the next period, and the success rate $\left(\sigma_{\mathrm{O}}\right)$ is sufficiently large (given composition of the population) that the next period's O population will have a majority composed of entrepreneurs $\left(\mathrm{O}_{\mathrm{E}}\right.$ plus successful $\left.\mathrm{O}_{\mathrm{LE}}\right)$, guaranteeing a policy of $\mathrm{g}=1$. Thus, there is no commitment problem under oligarchy. 
$\mathrm{g}_{2}$, and (iii) tyranny is sufficiently unattractive to the oligarches. ${ }^{24}$ This makes it optimal for the oligarch majority to establish democracy as a commitment device.

In other circumstances, the oligarches will find it optimal to resolve the time-inconsistency problem by appointing a tyrant from among the entrepreneurial oligarches. Although tyranny has a cost of $\tau$ per capita, the majority of the oligarches may find that the benefits of overcoming the time-inconsistency problem outweigh those costs. ${ }^{25}$ If that is so, and if switching to democracy would fail to solve the commitment problem (or if democracy would solve the problem but in a manner less beneficial to the oligarches), then the oligarches will install a tyrant. ${ }^{26}$ After installing a tyrant for period 2 , the oligarches may or may not let the tyrant rule for period 3 . This depends on the cost of removing the tyrant $(\rho)$ and the cost of having the tyrant in power $(\tau)$. For a given $\tau$, if

\footnotetext{
${ }^{24}$ To see more precisely how the commitment problem can occur, consider the following. If $\sigma_{\mathrm{O}} \beta_{\mathrm{O}}(3-$ $\left.\sigma_{\mathrm{O}}\right)-2(\gamma+1)>0$, then period 1 type $\mathrm{O}_{\mathrm{LE}}$ individuals would (along with type $\mathrm{O}_{\mathrm{E}}$ individuals) want to commit to $\mathrm{g}_{2}=\mathrm{g}_{3}=1$. That inequality holding makes commitment valuable, but commitment is not feasible under oligarchy if the following conditions hold: $\underline{\mathrm{O}}_{\mathrm{E}}+\sigma_{\mathrm{O}} \underline{\mathrm{O}}_{\mathrm{LE}}<.5 \underline{\mathrm{O}}$, which implies that period 2 investments $\left(\mathrm{k}_{2}=1\right)$ by type $\mathrm{O}_{\mathrm{LE}}$ individuals is insufficient to generate a period 2 majority composed of entrepreneurs; $\sigma_{\mathrm{O}} \beta_{\mathrm{O}^{-}}$ $(\gamma+1)<0$, which implies that type $\underline{\mathrm{O}}_{\mathrm{LE}}$ individuals unsuccessful in period 2 would prefer not investing and having $\mathrm{g}_{3}=0$ to investing and having $\mathrm{g}_{3}=1$. Under these circumstances, rational type $\mathrm{O}_{\mathrm{LE}}$ individuals would foresee (from period 1) a policy of $\mathrm{g}_{3}=0$ and, thus, not invest in period 2, thereby derailing economic growth.

Now consider why the oligarches may establish democracy in order to solve the commitment problem just described. There are three key conditions. First, the policy preferences of the type $D_{E}$ individuals must be sufficiently well aligned with those of type $\mathrm{O}_{\mathrm{E}}$ individuals. Note that if $\mu$ and $\delta$ are both sufficiently large, type $D_{E}$ individuals would set $d=1$ and $g=0$, thus giving the oligarches reason to avoid establishing democracy. Yet if $\mu$ and $\delta$ are instead sufficiently small, then the policy preferences will be closely aligned (e.g., if $\mu=0$ and/or $\delta=0$, then type $\mathrm{D}_{\mathrm{E}}$ individuals would (if there were any positive rents to going to entrepreneurs) set $\mathrm{d}=0$ and $\mathrm{g}=1$. Second, it must be the case that electorate setting $\mathrm{g}_{2}=1$ and $\mathrm{g}_{3}=1$ combined with investment by individuals is incentive compatible; this will be guaranteed if $\underline{\mathrm{O}}_{\mathrm{E}}+\sigma_{\mathrm{O}} \underline{\mathrm{O}}_{\mathrm{LE}}+\underline{\mathrm{D}}_{\mathrm{E}}+\sigma_{\mathrm{D}} \underline{\mathrm{D}}_{\mathrm{LE}}>.5(\underline{\mathrm{O}}+\underline{\mathrm{D}})$ and $\beta_{\mathrm{D}}>(\gamma+1) / \sigma_{\mathrm{D}}$. Third, the oligarchy must not prefer tyranny to democracy; a sufficiently large value of $\tau$ would guarantee this. When these three conditions hold, type $\mathrm{O}_{\mathrm{E}}$ and type $\mathrm{O}_{\mathrm{LE}}$ individuals will vote in period 1 to replace oligarchy with democracy.

${ }^{25}$ In the presence of a time-inconsistency problem (as set out in the previous footnote), the potential gain from resolving the problem is $\sigma_{\mathrm{O}} \beta_{\mathrm{O}}\left(3-\sigma_{\mathrm{O}}\right)-2(\gamma+1)$. Thus, if $\tau<.5\left[\sigma_{\mathrm{O}} \beta_{\mathrm{o}}\left(3-\sigma_{\mathrm{O}}\right)-2(\gamma+1)\right]$, type $\mathrm{O}_{\mathrm{E}}$ and type $\mathrm{O}_{\mathrm{LE}}$ individuals will prefer establishing a tyrant (even if the tyranny lasts through period 3 ) to an unresolved commitment problem.
}

${ }^{26}$ Sufficiently high values of $u$ and $\delta$ guarantee that the oligarches will not establish democracy. 
$\rho$ is sufficiently large, the oligarches will let tyranny continue, while if $\rho$ is sufficiently small, the oligarches will remove the tyrant. ${ }^{27}$

If the oligarches remove the tyrant, they may or may not enlist the help of the demos. Having the help of the demos benefits the oligarches by reducing the per-oligarch cost of removal, but it may cost the oligarches by resulting in public goods policies $\left(g_{3}<1, d_{3}>0\right)$ that differ from what the oligarches would view as ideal $\left(\mathrm{g}_{3}=1, \mathrm{~d}_{3}=0\right)$. More specifically, if the composition of the demos is such that democracy in period 3 will produce a majority composed of entrepreneurs, then for any given $\rho>0$, sufficiently low demand for good $d$ among the demos (low $\mu$ and $\delta$ ) gives oligarches the incentive to accept democracy in exchange for the reduction in their shares ( $r$ ) of the cost of removing the tyrant $(\rho)$. If, however, $\mu$ and $\delta$ are sufficiently large, the oligarches will find democracy less attractive than they will find the tyrant, and thus would not enlist the demos' support in removing the tyrant.

It is important to emphasize why the oligarches may be willing to establish democracy in period 3 after installing a (costly to remove) tyrant for period 2. Recall that the oligarches could move straight to democracy in period 2, but that may be too soon: A commitment problem can arise under democracy just as it arises under oligarchy. Thus, the key attribute of the demos underlying a transition to democracy via tyranny is not that the demos is composed of successful entrepreneurs to start, but that the period of tyranny allows sufficient growth in the segment of the demos that

${ }^{27}$ If $\rho>\tau(\underline{O}+\underline{D})$, then the oligarches would not choose to remove the tyrant, because even if the entire population (oligarches and demos) shared the cost, the per-oligarch cost of removing the tyrant would be higher than per-oligarch cost of having the tyrant in office. If $\rho<\tau \underline{\mathrm{O}}$, then the oligarches would choose to remove the tyrant, because even if the cost were shared only among the oligarches, the per-oligarch cost of removing the tyrant would be below the per-oligarch cost of having the tyrant in office. 
policy decisions under democracy will be aligned with the entrepreneurs among the oligarches. ${ }^{28}$

We will summarize the model's main implications as five cases:

Case 1. Neither Broadening Nor Narrowing: Stable O

Unless the oligarches face a time-inconsistency problem, they will neither install a tyrant nor enfranchise the demos. Thus, if an oligarchic government is dominated by landlords or by entrepreneurs, or if the expected gains to entrepreneurship among the oligarches are sufficiently high, then oligarchy will be stable.

Case 2. Durable Broadening: O to D

If there is a time-inconsistency problem under oligarchy but not under democracy, then the oligarches may enfranchise the demos. They will do so if policy decisions under democracy will be sufficiently well aligned with the policy preferences of the entrepreneurs among the oligarches.

Case 3. Durable Narrowing: $\mathrm{O}$ to $\mathrm{T}$

If there is a time-inconsistency problem under oligarchy, the oligarches may install a durable tyrant. They will do so if (i) the cost of having the tyrant rule is less than the benefits (which come in the form of resolving the commitment problem) and (ii) democracy would fail to solve the commitment problem or would otherwise be less attractive than tyranny. Even after there has been sufficient growth in entrepreneurship that the tyrant is no longer needed to resolve commitment problems, the tyrant will remain in power if removing the tyrant would cost more than having the tyrant rule.

\section{Case 4. Temporary Narrowing without Long Run Broadening: $\mathrm{O}$ to $\mathrm{T}$ to $\mathrm{O}$}

If the oligarches install a tyrant to resolve a commitment problem (as in Case 3), the tyrant will be replaced with oligarchy if (i) the per-oligarch cost of removing the tyrant is less than the per-oligarch cost of having the tyrant rule and (ii) the oligarches find democracy sufficiently less attractive than oligarchy that they are willing to bear the full cost of removing the tyrant.

Case 5. Temporary Narrowing with Long Run Broadening: $\mathrm{O}$ to $\mathrm{T}$ to $\mathrm{D}$

${ }^{28} \mathrm{An}$ easy way to see this is as follows. Recall that if $\sigma_{\mathrm{O}} \beta_{\mathrm{O}}\left(3-\sigma_{\mathrm{O}}\right)-2(\gamma+1)>0, \underline{\mathrm{O}}_{\mathrm{E}}+\sigma_{\mathrm{O}} \underline{\mathrm{O}}_{\mathrm{LE}}<.5 \underline{\mathrm{O}}$, and $\sigma_{\mathrm{O}} \beta_{\mathrm{O}}-(\gamma+1)<0$, there exists a time-inconsistency problem under oligarchy. Under those conditions, $\sigma_{\mathrm{D}}=\sigma_{\mathrm{O}}$, $\beta_{\mathrm{D}}=\beta_{\mathrm{O}},\left(\underline{\mathrm{D}}_{\mathrm{E}} / \underline{\mathrm{D}}\right)=\left(\underline{\mathrm{O}}_{\mathrm{E}} / \underline{\mathrm{O}}\right)$, and $\left(\underline{\mathrm{D}}_{\mathrm{LE}} / \underline{\mathrm{D}}\right)=\left(\underline{\mathrm{O}}_{\mathrm{LE}} / \underline{\mathrm{O}}\right)$ would generate a time-inconsistency problem under democracy. Therefore, if $\tau<.5\left[\sigma_{\mathrm{O}} \beta_{\mathrm{O}}\left(3-\sigma_{\mathrm{O}}\right)-2(\gamma+1)\right]$, tyranny would have positive expected net benefits for type $\underline{\mathrm{O}}_{\mathrm{LE}}$ individuals (and positive certain net benefits for type $\underline{\mathrm{O}}_{\mathrm{E}}$ individuals). So tyranny would be established if $\underline{\mathrm{O}}_{\mathrm{LE}}+\underline{\mathrm{O}}_{\mathrm{E}}>$.5 $\underline{\mathrm{O}}$. And tyranny would subsequently be replaced with democracy if, e.g., $\mu=0$. 
If the oligarches install a tyrant to resolve a commitment problem (as in Case 3), the tyrant will be replaced with democracy if (i) the per-oligarch cost of removing the tyrant (when shared with the demos) is less than the per-oligarch cost of having the tyrant rule and (ii) the oligarches find democracy sufficiently attractive that they will accept it in order to reduce their share of the cost of removing the tyrant. This second condition will be satisfied if a transitory period of tyranny allows sufficient growth in the segment of the demos that has policy preferences aligned with those of the entrepreneurs among the oligarches

We will begin our empirical analysis by testing the model's predictions on a data set of ancient Greek political institutions. We will then review the history of several tyrannies, to allow us to link the analysis to the model yet more tightly.

\section{THE DATA AND EMPIRICAL ANALYSIS}

The source of our data is the Hansen-Nielsen (2004) Inventory of Archaic and Classical Poleis. The Inventory, which took ten years to complete, summarizes all that is known about the political institutions of the large number of poleis identified in ancient sources. ${ }^{29}$ These poleis were scattered throughout the Greek world, as far west as Spain and as far east as the Black Sea. The Inventory provides information about the political institutions of 132 poleis; 46 of these 132 poleis are located on the Greek mainland. These 46 poleis will form the basis for our analysis. ${ }^{30}$

\footnotetext{
${ }^{29}$ The Inventory makes use of both formal literary sources from Hesiod onwards (e.g., fragmentary poems, Herodotus) and epigraphical sources (e.g., inscriptions on graves, public decrees). Information from later writers, such as Plutarch, is included if it was based on writings from Archaic or Classical period sources. See Hansen and Nielsen $(2004,9-10)$ for discussion. The written sources are supplemented by archaeological evidence, which can provide information about polis size and public building but usually tells us little about the polis' constitution.

${ }^{30}$ Thus, we are excluding poleis that were 1) colonies of other poleis, and/or 2) located on islands. With respect to the first, colonies were usually founded because of their commercial potential, making it more difficult to trace the link between commercial potential and tyranny. With respect to the second, the Greek islands (and poleis in Anatolia) always depended heavily on trade. For example, Boardman and Hammond (1982, v) write, "East Greece [Anatolia] and the Aegean islands led the way in exploration overseas and in the planting of new states. They depended upon the sea for different reasons [than the mainland]: the East Greek states, set along the coast of Turkey like a string of widely-spaced beads, trafficked with one another by sea, and most of the islands could support a rising population only by importing foodstuffs and raw materials." We also exclude Thessaly, where the polis as the Greeks knew it emerged only late in the Classical period. (Forrest 1982, 294 writes that "Thessaly was little other than a
} 
Before commencing, we should make two important points. First, the data set, as valuable as it is given how little is known about the political institutions of all but a few poleis, tells us only whether ancient sources report that a given poleis had a particular form of government (e.g., tyrant, democracy, popular assembly). Absence of a reported institution, of course, need not signify true absence of the institution. Therefore, as we investigate the data, we will discuss and correct for (to the degree possible) the problems this may raise.

Second, much of our analysis will rely on differences between poleis classified as "oligarchies" and those classified as "democracies." One of the astonishing things about ancient Greece is that by the mid-Classical period, nearly all of Greece was "democratic" in the sense that political (from "polis," of course) decisions were made collectively. That said, poleis differed with respect to the composition of the collective. It is best to consider the terms "oligarchy" and "democracy" as distinguishing between "narrow" and "broad" determinations of who can participate in the policy-making process. Oligarchies employed more stringent wealth-restrictions and assigned the most important duties to less representative political bodies. ${ }^{31}$ We also have, for a subset of the 46 poleis, more detailed information about specific political institutions.

Appendix B lists the mainland poleis that will be the focus of our analysis, along with

bigger, better Boeotia.... By and large, we are dealing with still another self-sufficient, stable agricultural society.")

${ }^{31}$ See Robinson (1997, Chapter 2) for a discussion of the term democracy (demokratia) as it was used in the Classical period (its earliest period of use) by Aristotle, Herodotus, Thucydides, pseudo-Xenophon, Aeschylus, and Euripides. He concludes that all have very similar concepts in mind. The term demokratia is first seen in pseudo-Xenophon's Constitution of the Athenians, written early in the $5^{\text {th }}$ century B.C.E. The principal characteristic of demokratia is the primacy of the demos, but the term is also associated with particular institutional features (such as ostracism and public pay for jurors), the most important of which is an absence of property qualifications for (most) offices. 
information about locations and political institutions, and other measures. ${ }^{32}$

\section{Did high growth potential lead to tyranny?}

The model predicts (as the history suggests) that tyrants arise where elites are divided, and that elites are divided where high commercial potential divides them. We do not have systematic measures of intra-elite divisions, nor of commercial potential. But we do have a plausible proxy for commercial potential: location on the coast. As discussed in Section II, a coastal (versus inland) location affected the cost of commercial activity (most trade was seaborne) and the relative benefits (land along the coast was generally less productive). Greece's greatest commercial powers, Megara, Corinth, and Athens, all possessed excellent harbors (not surprisingly). Very importantly, we can use coastal location as an exogenous proxy in our econometric framework - these mainland poleis were founded centuries before the Archaic period's economic revolution.

Table 1 divides the 46 poleis between the 11 for which tyranny was reported and the 35 for which it was not. As can be seen, of the 11 recorded tyrannies, ten were found in coastal poleis (the one exception, Pleious, was located on the navigable Asopos River). By contrast, of the 35 poleis where no tyrant was ever recorded, only 5 were located on the coast. ${ }^{33}$ Cutting the data differently, 10 of 15 coastal poleis are recorded as Archaic period tyrannies, versus only one of 31 inland poleis (and, as noted, that one was located on a river leading to the sea). Thus, coastal location - a proxy for high growth potential - is strongly associated with tyranny.

\footnotetext{
${ }^{32}$ Two mainland poleis are excluded: Astakos, for which nothing is known except that it once had a tyranny, and Megapolis, which was not founded until 368 B.C.E. (the tail end of the Classical period).

${ }^{33}$ Interestingly, four of the five were located on the Gulf of Corinth, which meant that they could reach the Aegean and sites to the south and west (Middle East, Anatolia, the Black Sea) only by sailing west and south, around the Peloponnese (or else having the ship towed across the Corinthian peninsula on a stone pathway - constructed by a tyrant, Periander - from the port of Corinth). In other words, these were locations less well-placed for trade.
} 


\section{Is the coast-tyranny correlation simply an artefact of what was recorded?}

The Hansen-Nielsen inventory only reports what ancient writers recorded. Thus, a concern is whether a higher reported incidence of tyranny on the coast may reflect not that coastal poleis were more likely to have tyrannies, but rather that tyrannies were more likely to be recorded when they were found on the coast. We will address this concern by estimating a probit that includes a variable measuring how much information the Inventory contains about each poleis, in columns of text. ${ }^{34}$ This variable is intended to capture both the survival of records and the level of interest a given polis generated among ancient writers. To take specific examples (see Appendix B), the Inventory contains 21 columns of text about Athens, 15 about Sparta, and eight about Argos - three of the bestknown poleis - as compared to 0.4 about Phelloe and 0.5 about Keryneia, two little-known poleis. The inclusion of the "columns of text" variable should reduce concern that Table 1 shows simply that both tyranny and coast were recorded for well-known places.

We begin with a univariate probit, to estimate the effects of coast on the likelihood of tyranny. The results shown in the first column of Table 2 are consistent with those of Table $1-$ location on the coast is associated with a 0.63 higher probability of tyranny. When we include our columns of text variable - the second column of Table 2 - we find that although more columns of text predicts a higher probability of tyranny, ceteris paribus, the effect of coast remains almost identical as when the "columns of text" variable is excluded. Thus, it seems unlikely that the relationship between coast and tyranny results from coastal poleis simply being better documented.

\section{Did tyranny lead to democracy?}

The next step is to examine the relationship between tyranny and democracy. We begin again

\footnotetext{
${ }^{34}$ This variable was calculated by Dispersed Authority Research Group at Stanford University, under the direction of Josh Ober. We thank them for making it available to us.
} 
with a simple table, dividing poleis between tyrannies and non-tyrannies (as recorded in the Inventory) - see Table 3 . The difference is striking. Of the 11 poleis that had tyrannies during the Archaic period, 10 were listed as democracies during the Classical period, while of the 35 poleis for which no Archaic period (or other) tyrannies were recorded, only 9 were listed as democracies during the Classical period. The remaining 26 were listed as oligarchies.

As before, we must ask whether the tyranny-democracy correlation is simply an artefact of what was recorded, and will again make use of the "columns of text" variable (our proxy for information available). The first column of Table 4 demonstrates a very strong relationship between tyranny and democracy, consistent with the data shown in Table 3. The second column shows the result of including the number of columns of text from the Inventory. The coefficient on tyranny falls somewhat, but is large enough to imply that tyranny is associated with a 0.43 higher probability of democracy. In short, the effect of tyranny on the likelihood of democracy does not appear to be a simple artefact of what was recorded.

As an additional test, we excluded members of the Delian League, Athens' unofficial “empire.” Our full sample of 46 mainland poleis has four Delian League members (Chalkis, Eretria, Histiaia, and Karystos). All four had tyrannies during the Archaic period and later became democracies - consistent with our hypothesis. However, Athens tended to promote democracy among its allies in an aggressive fashion, and if the four Delian League members would not have been democratic without pressure from Athens, our results could be distorted. Note that this would only be the case if these poleis would otherwise have been (i.e., in the counterfactual absence of the Delian League membership) “unusual”- that is, despite having Archaic period tyrannies, they would have been oligarchies in the Classical period. In any case, our econometric results leaving out the 
Delian League members are very similar to those shown in Table $4 .^{35}$

\section{Did the coast cause democracy directly?}

The foregoing results are consistent with the hypothesis that potential for growth led to tyranny, and that tyranny led to democracy. However, an obvious alternative explanation is that the potential for growth caused democracy directly, which would generate a non-causal correlation between tyranny and democracy. If our hypothesis is correct, we should see coast affecting democracy primarily through tyranny, while if the alternative is correct, we should see a very weak relationship between tyranny and democracy once coastal location is controlled for.

Table 5 shows the results of a horse race between coast and tyranny. The first column in Table 5 repeats the probit analysis from Table 4, to provide a basis for comparison; tyranny is associated with a 0.56 higher probability of democracy. The second column shows the result of replacing tyranny with coast. Coast also predicts democracy, as we would expect given our hypothesized causal chain running from coast to tyranny to democracy, but the point estimate is only about half the size of that on tyranny in column 1. The third column shows that when tyranny is included along with coast, coast no longer predicts democracy (the estimated effect of coast is negative and statistically insignificant), while the point estimate for tyranny is larger than in column 1. In columns 4-6, we show the results of re-running each of the three probits while adding columns of text as a control. Once again, the results indicate that coast predicts democracy through tyranny - matching the $\mathrm{O}$ to $\mathrm{T}$ to $\mathrm{D}$ path in our model.

\section{What can we say about institutions and wealth?}

We know that ancient Greece was unusual in its political institutions, and that it experienced

\footnotetext{
${ }^{35}$ The restricted-sample estimated effects of tyranny are: $0.515(\mathrm{z}=3.04)$ without columns of text, and $0.409(\mathrm{z}=2.00)$ with columns of text included as a control.
} 
tremendous economic growth from the Archaic priod through the Classical period (e.g., Morris 2009). Historical accounts provide ample evidence that many poleis - most famously, but by no means exclusively, Athens - were very wealthy. However, given that no good measures of wealth at the level of the polis exist, we cannot estimate the marginal effect of political institutions on wealth per se. That said, we have a proxy for wealth: public buildings. Public buildings were large and expensive, required wealth to construct, and the most famously wealthy poleis had the most of them (see Appendix B). Starr $(1977,37)$ writes that public buildings "provide a truly significant index of the vigor of Greek public life and of its underlying economic strength." Furthermore, the Greeks were similar in the types of public buildings they constructed, rendering the measure comparable across poleis. Our proxy for wealth will thus be the number of major public buildings, as listed in the Hansen-Nielsen Inventory. ${ }^{36}$

If our hypothesized causal chain of events is correct, we should see that the public buildings variable has high values for poleis that combined Archaic period tyranny with Classical period democracy. It is important to note that, although finding this would be consistent with our hypothesis, it is also consistent with other hypotheses. ${ }^{37}$ However, there is a testable prediction specific to our hypothesis: Tyranny and democracy will not be found together in poleis that are poor. In other words, finding few buildings in poleis that combined Archaic period tyranny and Classical period democracy would be evidence against our hypothesis.

Table 6 divides public buildings between the tyranny, oligarchy, and democracy categories.

\footnotetext{
${ }^{36}$ The variable sums theaters, stoa, gymnasia, stadia, hippodromes, and political architecture - see Hansen and Nielsen (2004, 1378).

${ }^{37}$ For example, actual wealth causes both tyranny and democracy. The difficulty is that we have no systematic information on when the buildings were built.
} 
Former tyrannies have 6.8 buildings listed on average, versus 3.2 for non-tyrannies. Democracies have 6.2 buildings on average, versus 2.5 for non-democracies. Ex-tyranny democracies average 7.0 public buildings, versus 5.2 buildings for democracies for which no tyranny was ever recorded. Thus, although what we can conclude from this comparison may be limited (the causal relationship between wealth and democracy can run in both directions), the differences between poleis are consistent with our argument that tyranny paved the way to wealth and democracy.

\section{An alternative measure of political institutions}

While we have attempted to address the possibility of non-random record-keeping through the inclusion of the "columns of text" variable in our estimations, the reasonableness of our interpretation of the results depends also on the accuracy with which ancient authors designated poleis democracies and oligarchies. For most of the sample, no detail other than these somewhat imprecise terms is provided. However, for a subset of the 46 poleis, we have more specific information on the type of political institutions. Twenty-one mainland Greek poleis are recorded as having employed a boule, a council of citizens whose responsibility was the day-to-day running of the affairs of the polis. ${ }^{38}$ By the Classical period, both democratic and oligarchic poleis employed boulai; the difference generally turned on whether the boule was the most important decision-making body (as in an oligarchy), or instead subordinate to a popular assembly (as in a democracy). ${ }^{39}$ Although systematic data on the specific rules governing boulai do not exist, we can observe whether

\footnotetext{
${ }^{38} \mathrm{~A}$ boule referred originally to a council of nobles that advised a king. Greek kings (basileis) disappeared during the Dark Ages in everywhere but Sparta.

${ }^{39}$ Andrewes $(1956,15)$ writes, “Almost all constitutional governments in Greece followed this pattern of council and assembly, with the difference that in developed democracy the probouleutic [boule] body was a large council of ordinary citizens chosen by lot for a year's term, but oligarchies preferred a smaller board with some special qualification, and often chosen for a long term or life. Further, the practice of oligarchies was to leave public business to the council and magistrates, with the full assembly playing a much smaller part, while in democracies the assembly tended to encroach in every direction."
} 
a people's assembly or people's court - two institutions characteristic of democracies - are recorded, as well. If they are, it appears plausible that power rested with the larger body of citizens; hence we have a democracy. But if only a boule is reported, it appears reasonable to conclude that the boule was the predominant decision-making body; hence we have an oligarchy.

Our identifying assumption is thus that the reporting of a boule signifies sufficiently detailed knowledge about political institutions that a people's assembly or court existing concurrently would have been recorded, too. ${ }^{40}$ That said, the nature of our test - a comparison of tyrant poleis to nontyrant poleis - should tend to reduce concern about under-reporting, in any case. To the degree that a people's assembly or court are recorded where boulai were in fact in charge, we under-report oligarchy and over-report democracy; to the degree some popular assemblies and courts are simply not mentioned when a boule is mentioned, despite the fact the assembly truly governed, we underreport democracy and over-report oligarchy. But unless these forms of under- or over-reporting are correlated with the recording of tyranny - and it is not obvious why they should be - comparison will not be biased. ${ }^{41}$

The result, shown in Table 7, is quite striking. None of the poleis reporting tyrants had only a boule (a sign of an oligarchy), while nearly two-thirds of the non-tyranny mainland poleis report only a boule. This is consistent with what we found using measures of democracy and oligarchy-

\footnotetext{
${ }^{40}$ For example, the Inventory says the following of the polis of Akraiphia: "The principal body of government was a boule to which only propertied citizens were admitted" (p. 437). And no popular assembly is recorded for Akraiphia. Note that our boule-based measure predicts democracy and oligarchy perfectly (with the exception of Delphi - a very unusual polis), suggesting that our democracy and oligarchy classifications are reasonable.

${ }^{41}$ We should reiterate that the rationale behind focusing on boulai is that the reporting of a boule signifies detailed knowledge of institutions, and therefore should not be associated with many instances of under-reporting of other institutions. In other words, within the set of poleis for which boulai are recorded, the reporting of a tyranny should not signify differential information about the tyrant polis' institutions.
} 
early tyranny is strongly associated with later democracy.

\section{EVIDENCE FROM HISTORICAL ACCOUNTS OF TYRANNY}

Our data demonstrate a strong link between the potential for economic growth, Archaic period tyranny, and Classical period democracy. However, they are insufficiently rich to allow us to test other of our model's predictions. For that, we must turn to historical accounts. We will focus on the best-documented Archaic period tyrannies (and near-tyrannies), and those of Athens in particular. From these, we will draw four main conclusions, each of which is consistent with our model's characterization of the transition process. First, the path to democracy via tyranny begins with divided elites $\left(\mathrm{O}_{\mathrm{E}}\right.$ vs $\left.\mathrm{O}_{\mathrm{L}}\right){ }^{42}$ Second, when tyrants come to power, they do so with the support of pro-commerce factions (type $\mathrm{O}_{\mathrm{E}}$ ). Third, the tyrant enacts growth-promoting policies, analogous to setting a high value of $\mathrm{g}$ in our model. ${ }^{43}$ Fourth, if tyranny lasts long enough for the policies to produce economic growth analogous to a high $\sigma_{\mathrm{D}}$ in our model, democracy follows, but not otherwise. Fifth, where exogenous conditions do not lead to a divided elite (e.g., $\left.\underline{\mathrm{O}}_{\mathrm{L}}=1\right)$, tyranny does not arise in the first place.

\footnotetext{
${ }^{42}$ Hall $(2007,45)$ writes, "The rise of tyrants can only really be satisfactorily explained against the background of internal frictions among elites."

${ }^{43}$ Most famously, tyrants invested in public works; however, they also took actions that reduced transaction costs and promoted the rule of law. Foremost among tyrant polices was investment in urban water infrastructure; Andrewes $(1982,414)$ writes "[C]oncern for the water-supply was a regular feature of early Greek tyrannies." Urban areas (and the artisans and factories they supported) required reliable water supplies to operate, and tyrants constructed aqueducts and well-houses. Tyrants undertook grander projects as well, including Cypselus of Corinth's cutting of the Leucas Canal, the construction of a commercial colonnade in Sicyon, the building a tunnel extending a kilometer through a hillside in Samos, and the paving of a four mile highway to haul ships and cargo over the Isthmus of Corinth. These investments were financed by market and harbor dues, rather than through direct taxes on agricultural output (Pisistratus of Athens was an exception, as we will discuss). Many tyrants standardized weights and measures and issued coinage.
} 


\section{Athens: Tyranny paves the way to democracy}

The best-documented tyrants, and prospective tyrants, are those of Athens. ${ }^{44}$ Late in the seventh century, a noble named Cylon attempted to become tyrant, failed, and was executed. Democracy did not follow. Early in the sixth century, another member of the nobility, Solon, was given supreme power. He enacted a series of reforms, was (by his own account) urged to become tyrant, but refused and stepped down. ${ }^{45}$ Democracy did not follow. Midway through the sixth century, yet another noble, Pisistratus, became tyrant. He and his sons ruled for the next several decades, and were followed by the establishment of democracy.

Cylon: A divided elite, a coup attempt, a dead would-be tyrant, no democratic transition

Although relatively little is known about Cylon, what is known fits our model. He was a prominent Eupitrad (noble). He attempted to become tyrant during a period of conflict between elite factions, approximately 632 B.C.E. Grant $(1987,42)$ writes, "his [Cylon's] attempted coup was not primarily inspired by democratic ideals, but was rather the product of sharp conflicts between the heads of different Eupatrid clans." Cylon's attempt failed and he was executed. The form of

${ }^{44}$ Historical evidence suggests that Athens was ruled originally by a king, but by the early Archaic period the king had been replaced by "archons," or magistrates. The archons were advised by a council, the Areopagus. The position of archon and membership in the Areopagus were restricted to the Eupatridae, or "men of noble birth," aristocratic families who controlled the policymaking process. There also may have existed a popular assembly to which all citizens belonged, but its influence on policymaking was believed to have been minimal and its function largely formal. See Andrewes (1982) for detail; he writes on that, "Before Solon it is beyond reasonable doubt that they [Eupatridae] alone were eligible for archonship" (p. 368). Archaeological evidence suggests that Athens boomed beginning in the eighth century B.C.E. - the number of detailed graves multiplied by sixfold and population growth rates may have reached 4 percent annually (Grant 1987, 39). Huge pots from the period, painted in late-Geometric style (for which an Athenian, the Dyplon Master, is credited) frequently depicted ships; from this, scholars deduce an interest in trade routes (Grant 1987, 38).

${ }^{45}$ As noted, "tyrant" was never a formal title. As far as is known, Solon served as archon, a magistrate, the most important of several archons, and it is likely that the tyrants who followed him (Pisistratus and Hippias) did the same. For more on Solon, see, e.g., Andrewes (1982, chapter 43). 
government was unchanged, and conflict between elite factions continued for several decades.

What does this show? First, attempted tyranny arose in the context of a divided elite (as in our model). Second, we can deduce from the failure of the attempt that the intra-elite conflict was unresolved (which is consistent with the fact that intra-elite conflict underlay the rise of Solon forty years later). In our model, the ascension of a tyrant signifies a victory by the commercially oriented segments (who then get public goods investment). Because the conflict was unresolved, the form of government remained (in the terminology of our model) O.

$\underline{\text { Solon: Reforms without a democratic transition }}$

Solon is one of the most famous figures in Athenian history, in part because he recorded his own achievements in (surviving) verse. He was from the merchant wing of the nobility - what Grant $(1987,46)$ refers to as "a new breed, a nobleman from a landowning family who had embarked on mercantile activity" (analogous to $\mathrm{O}_{\mathrm{E}}$ in our model). His rise to power- like Cylon's attempted rise - took place in the context of rivalry between aristocratic clans. According to tradition, Solon was appointed chief archon (magistrate) in 594/3 or 593/2. His ascension was presumably supported by a majority of the aristocratic factions, and he was granted extraordinary powers, which he used to enact a series of reforms. Solon is most famous for two of these reforms. The first altered the basis of political power from blood to wealth, which presumably increased the fraction of the ruling class that was pro-commercial $\left(\underline{\mathrm{O}}_{\mathrm{E}}\right)$, although it had little effect on most of the population. ${ }^{46}$ The second reform involved cancelling agricultural debts and forbidding the use of land or self as collateral. This would presumably have decreased the wealth and influence of the agricultural elite (who had benefitted from the rising concentration of land), while expanding the wealth and number of small

\footnotetext{
${ }^{46}$ Ober $(1996,38)$ writes that the political institutions established by Solon were "still quite rudimentary, and were still dominated by the elite."
} 
farmers. In the context of the model, one can view the increase in the number of small farmers as a rise in $\underline{\mathrm{D}}_{\mathrm{E}}$ or $\underline{\mathrm{D}}_{\mathrm{LE}}{ }^{47}$

Solon also passed a number of less sweeping laws. He required that all citizens teach their sons to read and write, and that all tradesmen teach their sons their crafts, essentially mandating a minimum level of $\mathrm{k}$ (in the form of human capital). He encouraged immigration to Athens by nonAthenian (metic) Greek craftsmen, the long run effect of which would have been to increase the size of the commercially oriented demos, $\underline{\mathrm{D}}_{\mathrm{E}}{ }^{48}$ He banned all agricultural exports except olive oil, Athens' main export (Athens was a large importer of grain), raising $\beta_{\mathrm{D}}$ by increasing the relative returns to olive production (olive trees required substantial investment). The ban would also have reduced the return to growing the grain that supported the agricultural branch of the aristocracy. ${ }^{49}$

Many of Solon's policies are similar to those attributed to successful tyrants elsewhere in Archaic Greece. So why was Solon's rule not followed by democracy? One straightforward possibility is that his term in office was simply too short. In our model, sufficiently great entrepreneurial success among the demos $\left(\sigma_{\mathrm{D}}\right)$ during the tyrant's rule is a necessary condition for tyranny to lead to democracy. Solon stepped down after only one year; not enough time for even the

${ }^{47}$ Small farmers grew olives and produced olive oil, Athens' principal export. Some small holders who lost their farms to lenders may have gotten them back as the result of Solon's reforms. Solon also set a ceiling on interest rates and extended state loans to small farmers (presumably necessary after outlawing the major forms of collateral). While the agricultural nobility held the fertile plains and grew grain, smallholders held less desirable, hilly, land, and grew olives. Policies that encouraged small farmers thereby increased the number of entrepreneurs. First, growing olive trees required large investments (k); see Fleck and Hanssen (2006). Second, the returns to this investment depended on pro-commerce policies - in the classical period, the lower the costs of trade, the higher the price of olives in Athens, because Athens exported olives (see Whitby 1998).

${ }^{48}$ Solon granted metics full protection of the law and made them eligible for military service (voluntary except in time of war), although he did not give them the right to own land.

${ }^{49}$ Solon also standardized weights and measures, reducing transaction costs and hence increasing g. 
most well-targeted of policies to have had much effect. ${ }^{50}$ His departure was followed, not by democracy, but by a renewal of intra-elite conflict.

\section{Pisistratus: Finally the $\mathrm{T}$ in the transition from $\mathrm{O}$ to $\mathrm{T}$ to $\mathrm{D}$}

The continued competition among Athenian elites culminated with the rise to power of the tyrant Pisistratus circa 546 B.C.E. Pisistratus may have been related to Solon and, like Solon, his official title was chief archon. Also like Solon, he wielded uncontested power. Traditional accounts suggest his rise was preceded by a struggle between three aristocratic factions: the parties of the Plain, the Coast, and the Hill. Some classicists have proposed that the Plain faction represented the agricultural elite $\left(\mathrm{O}_{\mathrm{L}}\right.$ in our model $)$, while the Coast faction consisted of the commercial elite $\left(\mathrm{O}_{\mathrm{E}}\right.$ in our model). The exact composition of the Hill faction, which Pisistratus led, is less clear, but it likely included components of $\mathrm{O}_{\mathrm{E}}, \mathrm{O}_{\mathrm{LE}}, \mathrm{D}_{\mathrm{E}}$, and $\mathrm{D}_{\mathrm{LE}} \cdot{ }^{51}$ Unlike Solon, Pisistratus ruled as tyrant for nearly twenty years, until he died in 527, and was succeeded by his sons, who ruled until exiled in 510. Thus, for 36 years (and perhaps longer) Athens was ruled by a tyrant. ${ }^{52}$

Less is known about Pisistratus than about Solon, largely because Pisistratus did not leave behind a written account. Grant $(1987,56-7)$ states that

Pisistratus was said to have governed the city with moderation, as a citizen rather than tyrant, supported by most of the nobility and people. The reason why the

\footnotetext{
${ }^{50}$ Whether he stepped down voluntarily (as he later claimed), or simply lacked the support needed to remain in power is not clear.

${ }^{51}$ In the long run, the hill areas of Athens were dominated by successful entrepreneurs who belonged to the demos - small holders on the hillside made the substantial investments in trees and equipment to grow olives. These small holders were enfranchised early in the Classical period.

${ }^{52}$ Note that 546 B.C.E., the year Pisistratus is said to have taken power, is nearly fifty years after the date given for Solon's resignation. The intervening time period is not well accounted for; furthermore, Solon was apparently still alive when Pisistratus served as tyrant (he is supposed to have advised Pisistratus). Thus, the gap between Solon's departure and Pisistratus' ascension may not have been this long, which would mean that Pisistratus ruled for more than twenty years - see Andrewes $(1982,393)$.
} 
nobility, on the whole, accepted him was because he was one of themselves and because he upheld the old tribal structure and ethic. But he insisted on restraining their internal conflicts - indeed this maintenance of public order was the basic raison d'etre of his regime.

Aristotle refers to the reign of Pisistratus as Athens' "golden age," crediting the tyrant for maintaining the peace while not interfering too much in the private affairs of citizens (Andrewes $1982,407) .{ }^{53}$

Pisistratus implemented a number of growth-promoting policies. He launched a major public building program - aqueducts, pump houses, and harbor facilities - that supported private investment in commerce. From the perspective of our model, these building programs can be viewed as components of g. ${ }^{54}$ He created a coast guard to police Athens' waters (Raaflaub 2007, 134), another complement to private investment (in sea-borne trade), and thus, again, a component of g. He established thirty circuit judgeships whose jurisdictions superceded that of local aristocracies. To the extent these reduced transactions costs and/or safeguarded investment, they also can be viewed as components of g. ${ }^{55}$ In addition, Pisistratus created a state fund to make loans to small farmers

\footnotetext{
${ }^{53}$ Pisistratus also did not meddle with Athens' formal political institutions, leaving intact Solon's constitutional reforms (which had left political powers in the hands of the well-to-do).

${ }^{54}$ Pisistratus is reputed to have funded these endeavors with the combination of a tax on agricultural output (one of the few recorded instances of a direct tax on agriculture in Archaic period Greece - see, e.g., Starr 1982, 433), and the use of revenues from Athens' silver mines.

${ }^{55}$ Athenian farmers invested substantially in olive trees and olive presses (olive oil was Athens' major export), fixed investments whose value could be opportunistically expropriated. Andrewes $(1982,407)$ writes that "the institution of 'traveling judges' presumably curtailed, at the least, judicial powers that the nobles had exercised locally." To the degree that the center (the tyrant) had less incentive or ability to expropriate local wealth, centralizing legal administration would have served to better guarantee investment by local farmers. Athenian olive oil was of such renown that it was used for prizes at athletic games (Andrewes 1982, 408). See Fleck and Hanssen (2006) for detail on property rights protection and the incentives to plant olive trees. Artisans' human capital investments would also have been highly complementary to the rule of law, especially because artisans were highly mobile. Indeed, tyrants competed to attract skilled artisans: Starr $(1982,430)$ writes that "Artisans and traders moved about the Greek world and even farther, and they could settle in foreign states as resident aliens (metics); a recent calculation suggests that at least half the potters and vase-painters known in Athens during black-figure and early red-
} 
(expanding $\left.\mathrm{D}_{\mathrm{LE}}\right){ }^{56}$ He may have seized land from fleeing aristocrats (reducing $\underline{\mathrm{O}}_{\mathrm{L}}$ ) and distributed it to small holders (which would also have increased $\underline{D}_{\mathrm{LE}}$ ).

Pisistratus's policies indeed appear to have promoted economic growth - Athens boomed during (and following) his rule. As Grant $(1987,61)$ writes:

In spite of subsequent prejudice against 'tyrants', it was admitted even by good later democrats, that the rule of Pisistratus could be looked back upon as a Golden Age. He had prudently refrained . . . from disturbing the existing Solonian constitution, or from otherwise encouraging any major social upheaval ... In addition, although dictatorship is not democracy - and Pisistratus, from a backseat, remained very much in charge, exercising control, for example, over elections - his regime had nevertheless, paradoxically, paved the way for the democratic system of the future. For he had restrained and tamed the Eupatrid nobility; and his astute guidance had provided a whole generation, over a wide spectrum of society, with a picture of how a state could be peacefully run.

The demos promotes democracy

After the expulsion from the poleis of Pisistratus' son, who served as tyrant until 510 B.C.E., an Athenian named Isagoras led an attempt to rescind the Solonian constitution and restrict political control to a small group of nobles (see, e.g., Ober 2007). Isagoras was supported by a contingent of troops from Sparta (Isagoras was an ally of the Spartan king, Cleomenes). An angered mass of Athenian citizens is said to have chased the Spartans, Isagoras, and Isagoras' supporters to the Acropolis and laid siege to it. After two days, the besieged party surrendered. The Spartans and Isagoras were permitted to leave; 300 of Isagoras' supporters were executed. Isagoras' rival, Cleisthenes, returned from exile, was appointed archon, and oversaw the enactment of reforms that

figure production had foreign names, even though they all worked fully within the Athenian artistic tradition." Thus, poleis with legal systems that better protected foreign artisans would have attracted more human capital, ceteris paribus.

${ }^{56}$ Although such a policy could be loosely considered g, making loans available is better viewed as contributing to the number of demos who would become successful entrepreneurs (thus increasing $\sigma_{\mathrm{D}}$ ). Reducing interest rates would also increase the returns to the successful (thus increasing $\beta_{\mathrm{D}}$ ). 
brought about the widespread enfranchisement of the demos. ${ }^{57}$ Athens was on its way to establishing the broadest democracy in ancient Greece.

$\underline{\text { Conclusions }}$

We cannot say precisely why Cylon failed to become a growth-generating tyrant, but one possibility is that he came along at a time when the commercial elite $\left(\mathrm{O}_{\mathrm{E}}\right)$ lacked sufficient numbers to dominate their rivals $\left(\mathrm{O}_{\mathrm{L}}\right)$, and the growth potential for would-be entrepreneurs $\left(\sigma_{\mathrm{E}}\right.$ and $\left.\sigma_{\mathrm{D}}\right)$ was not sufficiently high to allow a coalition with the commercial elite $\left(\mathrm{O}_{\mathrm{E}}\right)$. This also may have been true of Solon's time, but in any case, Solon's reforms could not - in the short period Solon ruled have created a demos that the elites would be willing to enfranchise: A short period of rule implies a small value of $\sigma_{D}$. What did lead to democracy was a period of type T government - initiated by Pisistratus - in which the Athenian government was credibly committed to policies that increased the expected returns to investment. And the success of the policies is evinced by the growth of the urban center, Athens proper. Cawkwell (1995, 80-1) writes,

By 510 B.C. things were very different [from when Pisistratus took power]. There was by then a people for whose support Cleisthenes could appeal, and with whose support he became superior to his rivals. The cause of this was quite simply, it may be suggested, the growth of the population of Athens itself. . . Since Athenian democracy was inevitably to a large extent rule by those who dwelt in or near the City as opposed to those scattered throughout Attica, growth of the city population was a necessary condition for the development of such a democracy. ${ }^{58}$

\section{Megara: Insufficiently durable tyranny}

The coastal polis Megara, located on the Isthmus of Corinth, was highly commercial and

\footnotetext{
${ }^{57}$ Cleisthenes' reforms put power front-and-center in the public assembly (in which each citizen had a voice), and eliminated the noble-dominated Council of 400 and Areopagus, replacing them with an advisory council whose membership was determined via lot from the population of all male citizens.

${ }^{58} \mathrm{~A}$ vivid example of how widely commerce-based wealth was distributed is the two Athenian potters who were sufficiently successful to have dedicated a bronze statue to Athena (Starr 1982, 437).
} 
highly successful during the Archaic period, and would appear to have been (like Athens) a prime candidate for a successful transition to democracy via tyranny. The Megarans were fortunate in having two harbors, one to the west on the Gulf of Corinth and the other to the south on the Saronic Gulf of the Aegean Sea. By the start of the $7^{\text {th }}$ century B.C.E., Megara was an important trading link between east and west.

Much less is known of Megara's history than of Athens', but it nonetheless provides a pertinent contrast. As in Athens, conflict between aristocratic factions led to the emergence of a tyrant, the Megaran noble Theagenes, who took power in the mid-to-late $7^{\text {th }}$ century. Hammond $(1983,345)$ writes,

As far then as the evidence goes (and it is very sketchy), we may conclude that tyranny grew out of oligarchy when the ranks of the oligarchs split and one factionleader among the oligarchs used force to seize power; and that sometimes he enlisted the help of a part of the common people.

Theagenes invested in public works, building a fountain house and tunneling a water conduit. $\mathrm{He}$ distributed some of the wealth of ousted aristocrats to the masses. Thus, as in Athens, the tyrant set out to provide a high level of $g$, and perhaps reduced $\underline{\mathrm{O}}_{\mathrm{L}}$ along the way.

Events played out differently in Megara than in Athens. After a relatively short rule, Theagenes was ousted in a popular uprising, and his ouster was followed by a the establishment of what Plutarch refers to as "unbridled democracy." The Megaran oligarches (whose wealth was presumably threatened by the new order) fought back, and the democracy was also short-lived, replaced by a narrow oligarchy (Hammond 1982, 350). Megara never did establish a durable democracy $^{59}$

${ }^{59}$ Megara was briefly democratic in 427 B.C.E., when a "democratic faction" seized power and exiled oligarches. Fighting followed, and in 424 B.C.E. the city gates were opened to Spartan troops, members of the democratic faction either went into exile or were executed, and a "radical" oligarchic constitution was 
Although we cannot know whether a more durable tyrant would have paved the way for a more democratic Megara, the fact that Megara's brief period of tyranny failed to generate a lasting democracy is consistent with our model's characterization of the process. When tyranny leads to democracy, as it did in Athens, it does so by ensuring the maintenance of growth promoting policies for a period long enough to generate a substantial increase in the segment of population that favors those policies. Megara's subsequent history suggests that, by ending tyranny abruptly, it chose the wrong institutional path. By the end of the $7^{\text {th }}$ century, Megara had lost its position as one of the leading powers in Greece, and shortly before 500, Megara submitted to Spartan domination, and joined the Peloponnesian League. ${ }^{60}$

\section{Sparta and Thebes: Undivided elite and no tyrants}

The pre-condition for a tyrant, as shown in our model and illustrated in the foregoing discussions, is a divided elite. Inland poleis, such as Thebes and Sparta, where wealth was based on agriculture, experienced no sharp intra-elite divisions. Of Thebes, Demand $(1982,9)$ writes:

The Theban oligarchy was relatively stable - for Greece, one might say it was exceptionally stable. . . . [there is] very little evidence of stasis [i.e., intra-elite conflict] in comparison with the active factionalism which dominated the politics of so many Greek cities.... The reason for the unusual political stability of Thebes was undoubtedly its economic stability. The economy of Thebes was predominantly agricultural, and the agricultural production was abundant.

Of Sparta, Forrest $(1968,64)$ writes, "while other [Greek] states acquired new interests, developed new internal tensions, made more political progress, Sparta remained static, as static as any human society can.” In Archaic Greece, intra-elite divisions were sparked by commercial potential, and

introduced, ending Megara's brief flirtation with democracy. See Hansen and Nielsen (2004, 464).

${ }^{60} \mathrm{~A}$ predominant trading power circa the $7^{\text {th }}$ century, Megara was superceded by Corinth in the $6^{\text {th }}$ century and by Athens in the $5^{\text {th }}$ century B.C.E. 
these poleis simply had less to gain from commerce. First, they were located inland from the sea, making transport of goods more costly. Demand $(1982,10)$ writes that even as late as the fifth century, "Thebes was not actively involved in trade on a scale which affected its fundamental outlook on life or its basic social structure." Second, like most inland poleis, Thebes and Sparta were sited where land was particularly fertile. ${ }^{61}$ Sparta controlled the rich plains of the Eurotas valley, while Thebes was set in the center of Boetia, one of Greece's most productive grain-growing areas.

In the context of the model, $\underline{\mathrm{O}}_{\mathrm{L}}$ remained large for these two poleis, and, therefore, oligarchy was stable. Indeed, as discussed in Section II, the elites in both states designed policies to make sure that commercially oriented factions would not come to power - nor even come into existence in Sparta. ${ }^{62}$ While this did not mean that neither Thebes nor Sparta could ever become democracies (Thebes indeed became a democracy late in the Classical period, although Sparta did not), the path did not require a tyrant.

\section{CONCLUSION}

This paper shows how economic performance and democracy may both depend on a combination of other factors: the potential for policy to promote growth, the initial allocation of productive assets, and which segments of the population stand to gain from investment. ${ }^{63} \mathrm{We}$ develop a model that demonstrates a plausible causal link running from potential economic growth

\footnotetext{
${ }^{61}$ Greece had little in the way of mineral resources, with some few exceptions, such as the Athenian silver mines. Hence, there was little but fertile land to attract inland settlers.

${ }^{62}$ Recall that Thebes permitted only those who had avoided commercial activities for at least ten years to hold public office, while Sparta banned commercial activity among its ruling elite completely.

${ }^{63}$ E.g., Barro (1997, 1999), Justman and Gradstein (1999), Minier (2001), and Mueller and Stratmann (2003), Fleck and Hanssen (2006), Acemoglu, Johnson, Robinson, and Yared (2008, 2009).
} 
to tyranny to democracy. We conduct an econometric analysis of data on Greek political institutions, and find strong empirical relationships consistent with our model's predictions. We present an analytical narrative that examines in some detail the history of Greek tyranny and confirms our interpretation of the econometric results. By doing these things, we make a unique contribution to understanding the circumstances that give rise to democracy.

Recall the quote from Thucydides with which we began this paper. If it were simply that as Thucydides suggests - tyranny was established where states had "grown more powerful" and were "still more than before engaged in the acquisition of wealth," we should expect economic growth to impede the development of democracy, by promoting tyranny via wealth. In fact, it appears that wealth and democracy went hand-in-hand in ancient Greece, via the mediating influence of tyranny. This conclusion highlights the importance of the institutional path to growth, development, and democracy. As Acemoglu, Johnson, Robinson, and Yared $(2009,1)$ write, "events during critical historical junctures can lead to divergent political-economic development paths, some leading to prosperity and democracy, others to relative poverty and non-democracy." ${ }^{964}$

Because we hypothesize a causal mechanism for the role of tyranny in democratic transitions, we can apply the lessons from our analysis to other times and places. Consider briefly three well known - and contrasting - examples of the rise of democracy: Britain, the United States, and France. In Britain, conflict between elite factions led to a broadening of the franchise (see Lizzeri and Persico 2004; Llavador and Oxoby 2005), not a narrowing to tyranny, as in Greece. A crucial difference between Britain and the Greek poleis was that rights in Britain had been gradually

${ }^{64}$ Consider Megara, a commercial success in the Archaic period that never experienced the growth or democracy achieved by Athens and others during the Classical period, after abruptly (prematurely?) abandoning tyranny. Or the failure of tyranny to lead to democracy following the brief rule of Solon. 
expanding for centuries. When the expansion is sufficiently gradual, there is no need for a period of tyranny (e.g., Jack and Lagunoff 2006). By contrast, the United States moved directly and quickly to democracy after the American Revolution. With its abundant land and resources, the U.S. had potential returns to investment and entrepreneurship (characterized by $\sigma_{\mathrm{D}}$ and $\beta_{\mathrm{D}}$ in our model) that were exceptionally high, allowing a tyranny-free transition to democracy (Case 2 of our model). A third path is illustrated by France, which experienced a revolution about the same time as did the United States, but lacked America's potential for economic growth (manifest in the U.S. frontier). The French Revolution, perhaps not surprisingly, failed to yield a lasting democracy ${ }^{65}$ Many of the growth-promoting policies that would enrich France in later years were enacted by Napoleon, an emperor who in many respects resembles an Archaic period Greek tyrant. Revolution.

${ }^{65}$ See Acemoglu, Cantoni, Johnson, and Robinson (2009) for an economic analysis of the French 


\section{BIBLIOGRAPHY}

Acemoglu, Daron, Davide Cantoni, Simon Johnson, and James A. Robinson. 2009. "The Consequences of Radical Reform: The French Revolution.” Working paper, MIT.

Acemoglu, Daron, Simon Johnson, James A. Robinson, and Pierre Yared. 2008. "Income and Democracy." American Economic Review 98:808-842.

Acemoglu, Daron, Simon Johnson, James A. Robinson, and Pierre Yared. 2009. "Reevaluating the Modernization Hypothesis.” Journal of Monetary Economics 56: 1043-1058

Acemoglu, Daron, and James A. Robinson. 2000. "Why Did the West Extend the Franchise? Democracy, Inequality and Growth in Historical Perspective." Quarterly Journal of Economics 115:1167-1199.

Acemoglu, Daron, and James A. Robinson. 2001. "A Theory of Political Transitions." American Economic Review 91:938-63.

Alesina, Alberto, and Allan Drazen. 1991. "Why are Stabilizations Delayed?" American Economic Review 81:1170-1188.

Alesina, Alberto, and Dani Rodrik. 1994. "Distributive Politics and Economic Growth." Quarterly Journal of Economics 109:465-490.

Anderson, Greg. 2003. The Athenian Experiment. Ann Arbor: University of Michigan Press

Andrewes, A. 1956. The Greek Tyrants. London: Hutchinson's University Library.

Andrewes, A. 1982. "The Growth of the Athenian State", in Boardman, John and N.G.L. Hammond, eds. The Expansion of the Greek World, Eighth to Sixth Centuries B.C., Cambridge, UK: The Cambridge Ancient History, ( $2^{\text {nd }}$ edition), vol III, part 3 (360-391)

Austin, M. M., and P. Vidal-Naquet. 1977. Economic and Social History of Ancient Greece, Berkeley: University of California Press.

Barro, Robert J. 1997. Determinants of Economic Growth. Cambridge: The MIT Press.

Barro, Robert J. 1999. “Determinants of Democracy.” Journal of Political Economy 107:S158-183.

Barzel, Yoram. 2000. "Property Rights and the Evolution of the State." Economics of Governance $1: 25-51$.

Boardman, John. 1977. "The Olive in the Mediterranean: Its Culture and Use" in Hutchinson, Joseph, ed., The Early History of Agriculture, Oxford University Press: Oxford, pp. 187-96. 
Boardman, John. 1982. "The Material Culture of Archaic Greece", in Boardman, John and N.G.L. Hammond, eds. The Expansion of the Greek World, Eighth to Sixth Centuries B.C., Cambridge, UK: The Cambridge Ancient History, (2 ${ }^{\text {nd }}$ edition), vol III, part 3 (442-461)

Cartledge, Paul, ed. 1998. The Cambridge Illustrated History of Ancient Greece, Cambridge University Press: Cambridge.

Cawkwell, G. L. 1995. "Early Greek Tyranny and the People.” The Classical Quarterly 45:73-86.

Conley, John P., and Akram Temimi. 2001. 'Endogenous Enfranchisement When Groups' Preferences Conflict." Journal of Political Economy 109:79-102.

Demand, Nancy H. 1982. Thebes in the Fifth Century, Routledge: London

Drews, Robert. 1972. “The First Tyrants in Greece.” Historia 21:129-144.

Fernandez, Raquel and Dani Rodrik. 1991. "Resistance to Reform: Status Quo Bias in the Presence of Individual-Specific Uncertainty.” American Economic Review 81:1146-1155.

Ferrill, A. 1972. "Herodotus on Tyranny." Historia 27:385-398.

Finley, Moses I. 1981. Early Greece: The Bronze and Archaic Ages, Norton: New York.

Fleck, Robert K. 2000. "When Should Market-Supporting Institutions Be Established?” Journal of Law, Economics, \& Organization 16:129-154.

Fleck, Robert K., and F. Andrew Hanssen. 2006. "The Origins of Democracy: A Model with Application to Ancient Greece." Journal of Law and Economics 49:115-146.

Fleck, Robert K., and F. Andrew Hanssen. 2009. “'Rulers Ruled by Women': An Economic Analysis of the Rise and Fall of Women's Rights in Ancient Sparta." Economics of Governance 10:221-245.

Freeman, Charles. 1999. The Greek Achievement. New York: Allen Lane Penguin Press.

Grant, Michael. 1987. The Rise of the Greeks. New York: Charles Scribner.

Hammond, N.G.L. 1982. “The Peloponnese.” In Boardman, John and N.G.L. Hammond, eds. The Expansion of the Greek World, Eighth to Sixth Centuries B.C., Cambridge, UK: The Cambridge Ancient History, (2 ${ }^{\text {nd }}$ edition), vol III, part 3 (321-359)

Hansen, Morgens H., and Thomas H. Nielsen. 2004. An Inventory of Archaic and Classical Poleis, Oxford: Oxford University Press.

Hanson, Victor D. 1999. The Other Greeks: The Family Farm and the Agrarian Roots of Western 
Civilization. Berkeley: University of California Press.

Jack, William, and Roger Lagunoff. 2006. "Dynamic Enfranchisement." Journal of Public Economics 90:551-572.

Jameson, Michael H. 1992. "Agricultural Labor in Ancient Greece.” Pp. 135-46 in Wells, Berit (ed.), Agriculture in Ancient Greece, Proceedings of the $7^{\text {th }}$ International Symposium at the Swedish Institute at Athens: Stockholm.

Justman, Moshe, and Mark Gradstein. 1999. "The Industrial Revolution, Political Transition, and the Subsequent Decline in Inequality in 19th-Century Britain." Explorations in Economic History $36: 109-127$.

Kiser, Edgar, and Yoram Barzel. 1991. "The Origins of Democracy in England." Rationality and Society 3:396-422.

Kydland, Finn E. and Edward C. Prescott. 1977. "Rules Rather than Discretion: The Inconsistency of Optimal Plans." Journal of Political Economy 85:473-491.

Kydland, Finn E. and Edward C. Prescott. 1980. "Dynamic Optimal Taxation, Rational Expectations and Optimal Control." Journal of Economic Dynamics and Control 2:79-91.

Krentz, Peter. 2007. "Warfare and Hoplites", in Shapiro, H.A., ed. The Cambridge Companion to Archaic Greece, Cambridge, UK: Cambridge University Press (61-84)

Lipset, Seymour Martin. 1959. "Some Social Requisites of Democracy: Economic Development and Political Legitimacy," 53 American Journal of Political Science 69-105.

Lizzeri, Alessandro, and Nicola Persico. 2004. "Why Did the Elites Extend the Suffrage? Democracy and the Scope of Government, With an Application to Britain's 'Age of Reform"', Quarterly Journal of Economics 119: 707-65.

Llavador, Humberto, and Robert J. Oxoby. 2005. "Partisan Competition, Growth, and the Franchise", Quarterly Journal of Economics 120: 1155-1189.

Londregan, John B., and Keith T. Poole. 1996. "Does High Income Promote Democracy?" 49 World Politics 1-30.

Lott, John R. Jr., and Lawrence W. Kenny. 1999. “Did Women's Suffrage Change the Size and Scope of Government?" 107 Journal of Political Economy 1163-1198.

McGuire, Martin C., and Mancur Olson. 1996. "The Economics of Autocracy and Majority Rule: The Invisible Hand and the Use of Force," 34 Journal of Economic Literature 72-96.

Minier, Jenny A. 2001. "Is Democracy a Normal Good? Evidence from Democratic Movements." 
67 Southern Economic Journal 996-1009.

Morris, Ian. 1996. "The Strong Principle of Equality and the Archaic Origins of Greek Democracy", in Ober, Josiah, and Charles Hedrick, editors, Demokratia: A Conversation on Democracies, Ancient and Modern, Princeton: Princeton University Press (19-48)

Morris, Ian. 2009. "Taking the Measure of History: Energy Capture Across the Last Twenty Thousand Years.” Working paper, Stanford University.

Mueller, Dennis C., and Thomas Stratmann. 2003. "The Economic Effects of Democratic Participation,” Journal of Public Economics 87:2129-2155.

Murray, Oswyn. 1993. Early Greece, Harvard University Press: Cambridge, MA.

North, Douglass C. 1990. Institutions, Institutional Change and Economic Performance. Cambridge: Cambridge University Press

North, Douglass C. 1993. "Institutions and Credible Commitment," 149 Journal of Institutional and Theoretical Economics 11-23.

North, Douglass C. and Barry R. Weingast. 1989. "Constitutions and Commitment: The Evolution of Institutions Governing Public Choice in Seventeenth Century England," 49 Journal of Economic History 803-832.

Ober, Josiah. 1996. The Athenian Revolution, Princeton, NJ: Princeton University Press

Ober, Josiah. 2007. “'I Besieged that Man’: Democracy’s Revolutionary Start” in Raaflaub, Kurt A., Josiah Ober, and Robert W. Wallace, editors, Origins of Democracy in Ancient Greece, Berkeley: University of California Press (83-104)

Olson, Mancur. 1993. "Dictatorship, Democracy, and Development." 87 The American Political Science Review 567-576.

Parker, Victor. 2007. "Tyrants and Lawgivers" in Shapiro, H.A., ed. The Cambridge Companion to Archaic Greece, Cambridge, UK: Cambridge University Press (13-39)

Pomeroy, Sarah B., Stanley M. Burstein, Walter Donlan, and Jennifer Tolbert Roberts. 1999. Ancient Greece: A Political, Social, and Cultural History. New York: Oxford University Press.

Raaflaub, Kurt A., and Robert W. Wallace. 2007. “'People's Power' and Egalitarian Trends in Archaic Greece", in Raaflaub, Kurt A., Josiah Ober, and Robert W. Wallace, editors, Origins of Democracy in Ancient Greece, Berkeley: University of California Press (22-48)

Raaflaub, Kurt A. 2007. “"The Breakthrough of Demokratia in Mid-Fifth Century Athens", in Raaflaub, Kurt A., Josiah Ober, and Robert W. Wallace, editors, Origins of Democracy in Ancient 
Greece, Berkeley: University of California Press (105-154)

Starr, Chester G. 1977. The Economic and Social Growth of Early Greece, 800-500 B.C. New York: Oxford University Press.

Starr, C.G. 1982. "Economic and Social Conditions in the Greek World", in Boardman, John and N.G.L. Hammond, eds. The Expansion of the Greek World, Eighth to Sixth Centuries B.C., Cambridge, UK: The Cambridge Ancient History, (2 ${ }^{\text {nd }}$ edition), vol III, part 3 (417-441)

Ure, P.N. 1922. The Origin of Tyranny, Cambridge University Press: Cambridge

Wallace, Robert W. 2007. "Revolutions and a New Order in Solonian Athens and Archaic Greece", in Raaflaub, Kurt A., Josiah Ober, and Robert W. Wallace, editors, Origins of Democracy in Ancient Greece, Berkeley: University of California Press (49-82)

Whitby, Michael. 1998. "The Grain Trade of Athens in the Fourth Century BC." In Parkins, Helen, and Christopher Smith, Trade, Traders, and the Ancient City, Routledge: New York, pp. 102-128.

White, Mary. 1954. “The Duration of the Samian Tyranny.” Journal of Hellenic Studies 74:36-43. 


\section{APPENDIX A: HISTORICAL BACKGROUND}

Scholars typically divide the history of Ancient Greece into four periods: the Mycenaean period (1600-1150 B.C.E.), the Dark Ages (1150-800 B.C.E.), the Archaic period (800-490 B.C.E.), and the Classical period (490-323 B.C.E.). (The Classical period traditionally ends with the death of Alexander the Great, although the institutions of the Greek city-state had been fundamentally and permanently changed by the earlier invasion of his father, Philip of Macedon.) The Mycenaean period was characterized by highly centralized, highly bureaucratic palace economies, similar to those seen in Crete at Knossos (and in Egypt and other near Eastern civilizations). The reason for the collapse of Mycenae remains a mystery. (For background on Mycenae and its collapse, see Austin and Vidal-Naquet 1977, Finley 1981, and Murray 1993.) Over the course of several decades in the late $12^{\text {th }}$ century, almost every Mycenaean center was attacked, plundered, and burned. The surviving remnants were attacked again about fifty years later, putting a definitive end to the period.

In the "Dark Ages" that followed (a time of "poverty, isolation, and illiteracy" according to Manville 1990, 35), the centralized palace bureaucracy that had controlled much of life vanished without a trace. Throughout Greece, precipitous declines in population occurred, estimated at 60 to 90 percent, depending on the region. Most Mycenaean sites were abandoned, and little collective memory of the earlier period appears to have survived. ${ }^{66}$ The Dark Ages thus represent a sharp break with what preceded it (see, e.g., Freeman 1993 and Pomeroy, et al. 1999, 41). The Dark-Age ruling elite, unlike the urban-dwelling elite of the Mycenaean period, lived in the countryside, supported largely by a pastoral economy. ${ }^{67}$ Dark-Age political institutions are believed to have been relatively simple: a council (boule) made up of local chieftains, a supreme chieftain/king (basileus), and an assembly of warriors (see Murray 1982, 59).

At the end of the $9^{\text {th }}$ century B.C. E. (the beginning of the Archaic period), population began to grow again, reaching rates of two to three percent per year by the early $8^{\text {th }}$ century (see Hanson 1999, 36 and the citations therein). Settled cultivation replaced the largely pastoral Dark Age economies, and poleis began to form, dominated by a form of government referred to by its rulers as "aristocracy," rule by the aristoi, or best.

\section{The emergence of the Classical polis}

As used in the Homeric poems, the word "polis" refers to a specific urban center (the original meaning of the word is "town"). However, the polis gradually came to encompass not just the single

${ }^{66}$ Murray $(1982,16)$ writes that the "Discontinuity with the past was nearly complete: later Greeks were unaware of almost all the important aspects of the world they portrayed in their heroic poetry." Pomeroy at al $(1999,39)$ write, "With the destruction of the [Mycenaean] palaces, the Near Eastern type of social and economic organization would disappear forever from Greece." Manville $(1990,35)$ notes that the Mycenaean period was "fundamentally distinct from the later society of the Geometric, Archaic, and Classical periods, and culturally separate from the latter era by the Dark Ages."

${ }^{67}$ Information about the Dark Ages is sketchy (hence the name). Although the Homeric epics may recount events of the Mycenaean period, scholars believe that the political and social institutions they describe are more representative of the late Dark Ages, when the poems were written down (between 740 and 720 B.C.E.). This hypothesis supported by recent excavations; see Pomeroy et al. $(1999,47-8)$ for details. 
city, but the surrounding terrain, and sometimes a series of smaller towns as well. The Classical polis of Athens, for example, comprised the entire peninsula of Attica, more than 1000 square miles. The process by which separate towns and independent countryside united as single poleis is somewhat obscure; later Greeks referred to it as syn-oikismos, the bringing together of the oikos ("families," usually associated with landholding). The process probably began as early as 900 B.C.E., reaching a peak between 750 and 700 B.C.E. It may have been driven in part by conflict between city-states over border lands (Hanson 1999, 251, 299-300). Because good agricultural terrain was relatively scarce in Greece, previously vacant land became the subject of active competition as populations grew. This contrasts sharply with Dark-Age conflicts, which were inspired primarily by a search for booty (Pomeroy, et al. 1999, 87).

The emergence of the polis was accompanied by corresponding changes in political institutions. Of foremost importance was a reduction in the power of kings (the office disappeared in most places) and an increase in the power of the broader nobility. The office of the king basileus - previously the single paramount political, military, and religious leader, was abolished in most places and weakened in others, and the office's governing duties were parceled out among several posts on a non-hereditary basis to officials (invariably members of the aristocracy) who served limited terms. The influence of the popular assembly also declined: The number of times the assembly could meet was restricted, as was the business that could be brought before it. In addition, property-holding requirements were established for sitting on the assembly.

\section{Explanations for the rise of the tyrant}

Although it has long been agreed that the Archaic period "Age of the Tyrant" was a time of commercial dynamism in Greece, and that tyrants arose where elites were divided, precisely why this unique institution developed remains a puzzle. ${ }^{68}$ Interpretive difficulty is compounded by the fact that, although many men were called tyrants by contemporary or later writers, "tyrant" was not an official title (there was no "office of tyrant"). ${ }^{69}$ As far as can be determined, most tyrants held regular magistracies (important posts once restricted to the nobility). Although poleis typically had several magistrates, tyrants exercised disproportionate power.

Various explanations have been advanced for the rise of the tyrant. The earliest derives from Aristotle, who said that tyrants appeared as champions of the demos (masses) when aristocracies became overbearing. Aristotle's explanation was widely accepted until the $20^{\text {th }}$ century, when scholars pointed out that there was little evidence aristocrats became more overbearing in the $7^{\text {th }}$ and $6^{\text {th }}$ centuries than they had been earlier, and relatively little that tyrants governed principally in the interests of the masses.

\footnotetext{
${ }^{68}$ The term tyrannos, from which "tyrant" is taken, is not Greek, and its original meaning is not well understood. Its earliest appearance in extant writing is in work by the Archaic poet Archilocus (circa $7^{\text {th }} \mathrm{c}$. B.C.E.), and refers to Gyges of Lydia, a wealthy non-Greek city in Asia Minor (Andrews 1956, 21). Some scholars have suggested that tyrannos is distinguished from basileus, the Greek word for king, in that kingship is hereditary while tyranny is not (e.g., Drews 1972,137). The problem with this explanation is that many ancient writers - Sophocles, Herodotus - appear to employ the terms somewhat interchangeably; see Parker $(2007,15)$.

${ }^{69}$ Andrewes $(1956,25)$ writes, "Tyranny was not a constitution, and the tyrant held no official position and bore no formal title."
} 
During the 20th century, an "economic" explanation of tyranny came to the fore: The appearance of coinage led to the creation of a capitalist class, which supported and was championed by the tyrant. ${ }^{70}$ This explanation is consistent with the rapid economic growth that occurred over the Archaic period, and accounted for the intra-elite conflicts and the commercial antecedents of many tyrants, as well as for tyrants' expenditures on public works that supported commerce (harbors, water supplies). However, it, too, fell into disfavor, as it was pointed out that tyrants often pre-dated the issuance of currency (without which large-scale trade was deemed to be impossible); indeed, the causality more plausibly went from tyrants to coinage. ${ }^{71}$ Critics also noted that many tyrants took actions that helped small farmers as well as the commercial classes. ${ }^{72}$

Recent work combines elements of the earlier theories, emphasizing that tyrants suppressed intra-elite conflict and established conditions under which poleis could thrive economically, but also that the demos ultimately benefitted from the tyrant's rule. See, e.g., Raaflaub and Wallace (2007).

${ }^{70}$ For example, Drews $(1972,131)$ writes, "Distressed that aristocrats monopolized all political power, the nouveaux riches backed a revolution that put into power a single ruler responsive to their wishes."

${ }^{71}$ There is ample evidence that trade does not requires coins. Starr $(1977,65)$ writes of Archaic Greece, "As far as one can see, bulk trade grew markedly both in volume and in the variety of items, though coinage and other aids to supple economic activity were not yet widely employed." Starr also notes that goods such as oxen and iron tripods were employed as means of exchange (108), and that the famous Phoenician traders of Carthage did not strike coins until currency was needed to pay mercenaries (113).

${ }^{72}$ Another explanation links tyranny to the emergence of hoplite warfare in the $7^{\text {th }}$ century (e.g., Drews 1972; Andrewes 1956). But it is now largely believed that hoplite warfare developed gradually and may not have coalesced into the disciplined phalanx until the fifth century B.C.E. (e.g., Krentz 2007). 
APPENDIX B: BASE DATA SET

\begin{tabular}{|c|c|c|c|c|c|c|c|c|c|c|c|c|c|}
\hline Polis & $\begin{array}{l}\text { Inv. } \\
\text { Number }\end{array}$ & Region & Coast & $\begin{array}{l}\text { Archaic } \\
\text { Tyranny }\end{array}$ & date & Oligarchy & date & Democracy & date & $\begin{array}{l}\text { Columns } \\
\text { text }\end{array}$ & $\begin{array}{l}\text { Public } \\
\text { buildings }\end{array}$ & Boule & $\begin{array}{l}\text { Assembly/ } \\
\text { court }\end{array}$ \\
\hline Aigai & 229 & 12 & no & no & & yes & $\mathrm{C} 5-\mathrm{C} 4$ & no & & 1.2 & 0 & & \\
\hline Aigeira & 230 & 12 & no & no & & yes & $\mathrm{C} 5-\mathrm{C} 4$ & no & & 1.4 & 3 & & \\
\hline Aigion & 231 & 12 & yes & no & & yes & $\mathrm{C} 5-\mathrm{C} 4$ & no & & 1.2 & 2 & & \\
\hline Akraiphia & 198 & 10 & no & no & & yes & $\mathrm{C} 5-\mathrm{C} 4$ & no & & 2 & 3 & yes & \\
\hline Ambrakia & 113 & 6 & yes & yes & $\mathrm{C} 6$ & yes & C6-C5 & yes & $\mathrm{C} 4$ & 3.1 & 3 & & \\
\hline Argos & 347 & 18 & yes & yes & C6 & yes & C6-C5 & yes & $\mathrm{C} 5-\mathrm{C} 4$ & 7.9 & 11 & yes & yes \\
\hline Athens & 361 & 20 & yes & yes & C6 & yes & C8-C6 & yes & $\mathrm{C} 6-\mathrm{C} 4$ & 20.8 & 20 & yes & yes \\
\hline Chaironeia & 201 & 10 & no & no & & yes & $\mathrm{C} 5-\mathrm{C} 4$ & no & & 1.6 & 3 & yes & \\
\hline Chaleion & 159 & 8 & yes & no & & yes & C5 & no & & 0.9 & 2 & & \\
\hline Chalkis & 365 & 21 & yes & yes & C6 & yes & $\mathrm{C} 6, \mathrm{C} 5$ & yes & $\mathrm{C} 6, \mathrm{C} 5-\mathrm{C} 4$ & 4.4 & 2 & & \\
\hline Corinth & 227 & 11 & yes & yes & C7-C6 & yes & $\mathrm{C} 8-\mathrm{C} 7, \mathrm{C} 6-\mathrm{C} 4$ & yes & $\mathrm{C} 4$ & 6 & 9 & yes & yes \\
\hline Delphoi & 177 & 9 & no & no & & yes & $\mathrm{C} 4$ & no & $\mathrm{C} 4$ & 8.3 & 9 & yes & \\
\hline Dyme & 234 & 12 & no & no & & yes & $\mathrm{C} 5-\mathrm{C} 4$ & no & & 1.9 & 2 & & \\
\hline Elis & 251 & 13 & no & no & & yes & $\mathrm{C} 6-\mathrm{C} 5$ & yes & $\mathrm{C} 5-\mathrm{C} 4$ & 8 & 7 & yes & yes \\
\hline Epidauros & 348 & 18 & yes & yes & $\mathrm{C} 7$ & yes & C7 & yes & $\mathrm{C} 4$ & 4.4 & 6 & yes & yes \\
\hline Haliartos & 206 & 10 & no & no & & yes & $\mathrm{C} 5-\mathrm{C} 4$ & no & & 1.9 & 4 & yes & \\
\hline Helisson & 273 & 14 & no & no & & no & & yes & $\mathrm{C} 4$ & 1.3 & 0 & & \\
\hline Heraia & 274 & 14 & no & no & & no & & yes & $\mathrm{C} 4$ & 2.2 & 4 & & \\
\hline Histiaia/Oreos & 372 & 21 & yes & yes & $\mathrm{C} 7$ & yes & $\mathrm{C} 5$ & yes & $\mathrm{C} 5, \mathrm{C} 4$ & 4.1 & 3 & yes & yes \\
\hline Hyettos & 207 & 10 & no & no & & yes & $\mathrm{C} 5-\mathrm{C} 4$ & no & & 1.1 & 1 & yes & \\
\hline Karystos & 373 & 21 & yes & no & & yes & C5 & yes & $\mathrm{C} 5$ & 2.5 & 3 & & \\
\hline Keryneia & 236 & 12 & no & no & & yes & $\mathrm{C} 5-\mathrm{C} 4$ & no & & 0.5 & 1 & & \\
\hline Kopai & 209 & 10 & no & no & & yes & $\mathrm{C} 5-\mathrm{C} 4$ & no & & 1 & 2 & yes & \\
\hline Koroneia & 210 & 10 & no & no & & yes & $\mathrm{C} 5-\mathrm{C} 4$ & no & & 2 & 4 & yes & \\
\hline Leontion & 237 & 12 & no & no & & yes & $\mathrm{C} 5-\mathrm{C} 4$ & no & & 0.4 & 1 & & \\
\hline Mantineia & 281 & 14 & no & no & & yes & $\mathrm{C} 4$ & yes & $\mathrm{C} 4$ & 5.6 & 8 & yes & yes \\
\hline Megara & 225 & 11 & yes & yes & C7 & yes & $\mathrm{C} 7, \mathrm{C} 6$ & yes & $\mathrm{C} 5-\mathrm{C} 4$ & 4.7 & 5 & yes & yes \\
\hline Olenos & 238 & 12 & no & no & & yes & $\mathrm{C} 5-\mathrm{C} 4$ & no & & 0.8 & 0 & & \\
\hline Opous & 386 & 22 & no & no & & yes & $\mathrm{C} 5$ & no & & 2.9 & 2 & & \\
\hline Orchomenos & 213 & 10 & no & no & & yes & $\mathrm{C} 5-\mathrm{C} 4$ & no & & 3.5 & 5 & yes & \\
\hline
\end{tabular}




\begin{tabular}{|c|c|c|c|c|c|c|c|c|c|c|c|c|}
\hline Pharai & 241 & 12 & no & no & & yes & $\mathrm{C} 5-\mathrm{C} 4$ & no & & 0.6 & 0 & \\
\hline Phelloe & 242 & 12 & no & no & & yes & $\mathrm{C} 5-\mathrm{C} 4$ & no & & 0.4 & 0 & \\
\hline Phigaleia & 292 & 14 & no & no & & no & & yes & $\mathrm{C} 4$ & 2.2 & 5 & \\
\hline Phleious & 355 & 18 & no & yes & C6 & yes & $\mathrm{C} 4$ & yes & $\mathrm{C} 4$ & 3.5 & 4 & \\
\hline Plataia & 216 & 10 & no & no & & no & & yes & $\mathrm{C} 5$ & 3.8 & 4 & \\
\hline Rhypai & 243 & 12 & no & no & & yes & $\mathrm{C} 5-\mathrm{C} 4$ & no & & 0.9 & 0 & \\
\hline Sikyon & 228 & 11 & yes & yes & C7-C6 & yes & $\mathrm{C} 6-\mathrm{C} 4$ & no & & 4.2 & 5 & \\
\hline Siphai & 218 & 10 & yes & no & & yes & $\mathrm{C} 5$ & no & & 1 & 2 & \\
\hline Sparta & 345 & 17 & no & no & & yes & $\mathrm{C} 8-\mathrm{C} 4$ & no & & 14.7 & 5 & \\
\hline Tanagra & 220 & 10 & no & no & & yes & $\mathrm{C} 5-\mathrm{C} 4$ & no & & 2.4 & 5 & yes \\
\hline Tegea & 297 & 14 & no & no & & yes & $?-\mathrm{C} 4$ & yes & $\mathrm{C} 4$ & 4.9 & 6 & yes \\
\hline Thebes & 221 & 10 & no & no & & yes & $\mathrm{C} 6-\mathrm{C} 4$ & yes & $\mathrm{C} 4$ & 5.7 & 10 & yes \\
\hline Thespiai & 222 & 10 & no & no & & yes & $\mathrm{C} 5-\mathrm{C} 4$ & no & & 3 & 3 & yes \\
\hline Tritaia & 244 & 12 & no & no & & yes & $\mathrm{C} 5-\mathrm{C} 4$ & no & & 0.6 & 0 & \\
\hline
\end{tabular}

SOURCE: Hansen and Nielsen (2004)

Inventory number refers to listing in Hansen and Nielsen (2004)

Region codes can be found in Hansen and Nielsen (2004)

Coast signifies poleis located on coast

Dates refer to century B.C.E.

Columns text are columns of text in Hansen and Nielsen (2004)

Public buildings refers to total number of public buildings constructed by the polis (walls, political buildings, temples, theaters, stoa, gymnasia, stadia, hippodromes) 


\title{
TABLE 1: TYRANNY AND LOCATION ON COAST
}

\author{
Number On Coast
}

Tyranny recorded

$11 \quad 10$

No tyranny recorded

35

5 


\section{TABLE 2: TYRANNY AND LOCATION ON COAST \\ (Probit)}

Dependent variable $=1$ if tyranny

(1)

(2)

$\underline{\text { Marginal effects }}$

$\underline{\text { Variable }}$

$\begin{array}{lll}\text { coast } & 0.634 & 0.628 \\ & (5.04) & (4.43)\end{array}$

columns of text $\quad 0.037$

(1.91)

$\begin{array}{lll}\text { Pseudo-R2 } & 0.45 & 0.55\end{array}$

No. Obs. $\quad 46 \quad 46$

z-statistics in parentheses 


\section{TABLE 3: TYRANNY AND CLASSICAL PERIOD DEMOCRACY}

Democracy during

Classical period

10

9
No democracy

during Classical period
Tyranny recorded

No tyranny recorded
1

26 


\section{TABLE 4: TYRANNY AND DEMOCRACY \\ (Probit)}

Dependent variable $=1$ if democracy

(1)

Marginal effects

$\underline{\text { Variable }}$

tyranny

$0.561 \quad 0.427$

(4.07) (2.80)

columns of text

0.048

(1.77)

Pseudo-R2

No. Obs.

0.18

46

0.24

46

z-statistics in parentheses 
TABLE 5: TYRANNY, COAST, AND DEMOCRACY

(Probit)

Dependent variable $=1$ if democracy

\begin{tabular}{|c|c|c|c|c|c|c|}
\hline & $\begin{array}{l}\text { (1) } \\
\text { Marg }\end{array}$ & $\begin{array}{l}\text { (2) } \\
\text { ts }\end{array}$ & (3) & (4) & (5) & (6) \\
\hline Variable & & & & & & \\
\hline tyranny & $\begin{array}{l}0.561 \\
(4.07)\end{array}$ & & $\begin{array}{l}0.628 \\
(3.59)\end{array}$ & $\begin{array}{l}0.427 \\
(2.80)\end{array}$ & & $\begin{array}{l}0.517 \\
(2.27)\end{array}$ \\
\hline coast & & $\begin{array}{c}0.309 \\
(2.96)\end{array}$ & $\begin{array}{l}-0.121 \\
(-0.51)\end{array}$ & & $\begin{array}{l}0.259 \\
(1.57)\end{array}$ & $\begin{array}{c}-0.067 \\
(-0.27)\end{array}$ \\
\hline columns of text & & & & $\begin{array}{l}0.048 \\
(1.77)\end{array}$ & $\begin{array}{l}0.062 \\
(2.39)\end{array}$ & $\begin{array}{l}0.047 \\
(1.71)\end{array}$ \\
\hline Pseudo-R2 & 0.18 & 0.07 & 0.19 & 0.24 & 0.17 & 0.24 \\
\hline No. Obs. & 46 & 46 & 46 & 46 & 46 & 46 \\
\hline
\end{tabular}

z-statistics in parentheses 


\title{
TABLE 6: WEALTH (PUBLIC BUILDINGS) AND DEMOCRACY
}

\author{
Average \# public buildings
}

$\begin{array}{ll}\text { Tyrannies } & 6.8\end{array}$

Non-tyrannies

3.2

Democracies

6.2

-Democracies, formerly tyrannies

-Democracies, never tyrannies

5.2

Non-democracies

2.5

-Non-democracies, formerly tyrannies 5.0

-Non-democracies, never tyrannies

2.4 
TABLE 7: POLEIS REPORTING BOULAI

Boule recorded

with popular assembly

Tyranny recorded

No tyranny recorded
7

5
Boule recorded

alone

0

9 